\title{
O DIREITO A INTIMIDADE COMO LIMITE À ADMISSIBILIDADE DAS GRAVAÇÕES CLANDESTINAS: REFLEXÕES ACERCA DA POSIÇÃO DO SUPREMO TRIBUNAL FEDERAL
}

\author{
THE RIGHT TO INTIMACY AS A LIMIT TO THE ADMISSIBILITY OF CLANDESTINE \\ RECORDINGS: REFLECTIONS ON THE POSITION OF THE BRAZILIAN SUPREME \\ FEDERAL COURT
}

\begin{abstract}
Marco Antonio Marques da Silva
Professor Titular (Livre-Docente, Doutor e Mestre) em Direito Processual Penal da Pontifícia Universidade Católica de São Paulo. Conselheiro do Conselho Nacional de Educação. Professor Catedrático da Universidade Europeia (Portugal) e Professor Visitante da Faculdade de Direito da Universidade de Lisboa. Desembargador do Tribunal de Justiça de São Paulo (aposentado).

E-mail: ezms@uol.com.br

\section{Régis Munari Furtado}

Doutorando e Mestre em Direito Processual Penal pela Pontifícia Universidade Católica de São Paulo. Especialista em Direito Penal Econômico pela Universidade de Coimbra/IBCCrim. Professor Assistente nos Cursos de Extensão e Especialização da COGEAE/PUC-SP. Advogado. E-mail: regismunari1@ hotmail.com
\end{abstract}

Recebido em: 06/04/2020

Aprovado em: 13/10/2020

RESUMO: A admissibilidade das gravações clandestinas como meio de prova no processo penal proporcionou inúmeras discussões no âmbito do Supremo Tribunal Federal, notadamente a partir da Constituição de 1988 que, dentre outros direitos e garantias individuais, previu o direito à intimidade (art. 5. ${ }^{\circ}, \mathrm{X}$ ). A partir do RE n..$^{\circ}$ 583.937-RG-QO/RJ, o Plenário do Excelso Pretório passou a admitir, de forma ampla e irrestrita, a utilização das gravações ambientais como meio de prova, ignorando a necessidade de estabelecer parâmetros adequados para a sua utilização. O presente estudo busca, assim, por meio do método dedutivo, refletir acerca do entendimento fixado pela Suprema Corte, bem como a utilização das gravações clandestinas, evitando-se, em consequência, arbitrariedades e a validação de provas que são, por regra, flagrantemente ilícitas.

Palavras-chave: Direito à intimidade. Provas ilícitas. Gravações clandestinas. Interceptações.

\begin{abstract}
The admissibility of clandestine recordings as evidence in criminal proceedings has led to numerous discussions in the Brazilian Supreme Court, notably from the 1988 Constitution which, among other rights and individual guarantees, provided for the right to privacy (art. 5, X). Since RE n. ${ }^{\circ}$ 583.937-RG-QO/RJ, the Plenary of the Brazilian Supreme Court has broadly and unrestrictedly accepted the use of environmental recordings as evidence, ignoring the need to establish appropriate parameters for its use. use. The present study thus seeks to reflect on the understanding established by the Brazilian Supreme Federal Court, as well as the use of clandestine
\end{abstract}


recordings, thus avoiding arbitrariness and the validation of evidence that is, as a rule, flagrantly illicit.

Keywords: Right to intimacy. Illicit evidence. Clandestine recordings. Interceptions.

SUMÁRIO: Introdução. 1 Direito à prova: a intimidade como limite probatório no processo penal. 2 Provas ilícitas e ilegítimas: tratamento constitucional, legal e o princípio da proporcionalidade. 3 Provas ilícitas por derivação e a teoria dos frutos da árvore envenenada. 4 Interceptações e gravações clandestinas: distinções necessárias. 5 O Supremo Tribunal Federal e as gravações clandestinas: ausência de tratamento sistemático. 6 A intimidade como limite à admissibilidade das gravações clandestinas: uma proposta de revisão. Considerações finais. Referências.

\section{INTRODUÇÃO}

A possibilidade de utilização da gravação clandestina como meio de prova tem, apesar das inúmeras discussões travadas no Supremo Tribunal Federal, dispensado pouca atenção por parte da doutrina brasileira ${ }^{1}$. Muito embora o tema tenha sido apreciado pelo Plenário do Pretório Excelso no RE n. ${ }^{\circ}$ 583.937-RG-QO/RJ, pelo qual declarou-se "lícita a prova consistente em gravação ambiental realizada por um dos interlocutores sem conhecimento do outro", a questão ainda apresenta espaços para crítica.

O estudo ora apresentado busca, assim, por meio do método dedutivo, analisar o direito à intimidade como limite à admissibilidade das gravações clandestinas, algo que, aparentemente, restou ignorado pela Suprema Corte quando da discussão da matéria no precedente supra firmado, apresentando, ao final e com fundamento da doutrina, uma contribuição ao entendimento consolidado, com vetores tendentes a evitar a banalização de tais provas, as quais possam vir a fugir dos limites constitucionais e legais possíveis.

Para tanto, promovemos, ao longo do estudo, a análise da intimidade como limite à prova no processo penal, as implicações dessa garantia constitucional, bem como os aspectos jurídicos ligados ao assunto. Discutimos, na sequência, o tratamento constitucional e legal das provas ilícitas no ordenamento pátrio, notadamente com as mudanças promovidas pela Lei n. ${ }^{\circ} 11.690$, de 9 de junho de 2008 ao art. 157 do Código de Processo Penal, verificando, ainda, a aplicação do princípio da proporcionalidade e a admissibilidade das provas ilícitas em prol do acusado ou da acusada.

Examinamos, outrossim, as provas ilícitas por derivação, apresentando alguns posicionamentos jurisprudenciais sobre a temática, bem como das hipóteses de ausência de nexo causal e da teoria da fonte independente. Também é apresentado, em continuidade, as distinções que se estabelecem entre as interceptações e gravações clandestinas e o tratamento dispensado a essas duas modalidades de captação.

Anotamos, igualmente, a ausência de tratamento sistemático, pelo Supremo Tribunal Federal, das gravações clandestinas, apontando a evolução jurisprudencial do tema, notadamente o RE n. ${ }^{\circ}$ 583.937-QO-RG/RJ que passou a admitir, indistintamente e sem qualquer critério, toda e qualquer situação de gravação ambiental, à exceção das hipóteses em que a legislação imponha vedação legal explícita.

Na última parte do trabalho, trazemos uma proposta baseada no direito à intimidade e na doutrina relacionada sobre o tema, estabelecendo parâmetros limitados para que as gravações clandestinas possam ser admitidas no processo penal, sem incorrer em hipótese de ilicitude.

\footnotetext{
${ }^{1}$ Sobre a falta de análise crítica do instituto, cf. AMBOS, Kai; LIMA, Marcellus Polastri Lima. O processo acusatório e a vedação probatória: perante as realidades alemã e brasileira. Porto Alegre: Livraria do Advogado, 2009. p. 168. Revista de Direito Brasileira | Florianópolis, SC | v. 26 | n. 10 | p. 365-386 | Mai./Ago. 2020
} 


\section{DIREITO À PROVA: A INTIMIDADE COMO LIMITE PROBATÓRIO NO PROCESSO PENAL}

Os princípios constitucionais em razão de objetivarem a proteção do direito à liberdade, sobressaem em importância no que diz respeito ao processo penal. Exatamente por isso, têm eles o papel não apenas de assegurar a realização da justiça, mas, sobretudo, de prescrever a legalidade e garantir o respeito aos direitos dos que se vê submetido a atividade persecutória do Estado ${ }^{2}$.

Em termos legislativos, entendemos que o direito à prova provém do princípio constitucional do devido processo legal, materializado pelo art. 5. ${ }^{\circ}$, LIV, da Constituição Federal, segundo o que "ninguém será privado da liberdade ou de seus bens sem o devido processo legal"3. No âmbito dos tratados internacionais de direitos humanos, o Pacto Internacional sobre os Direitos Civis e Políticos e o Pacto de São José da Costa Rica, recebidos no Brasil com força de emenda à constituição por força do art. $5^{\circ}, \S 2 .^{\circ}$, da Constituição ${ }^{4}$, dispõem, como garantias mínimas em favor do acusado ou da acusada, o "de interrogar ou fazer interrogar as testemunhas de acusação e de obter o comparecimento e o interrogatório das testemunhas de defesa nas mesmas condições de que dispõem as de acusação" (art. 14, 3, "e") e o "direito da defesa de inquirir as testemunhas presente no tribunal e de obter o comparecimento, como testemunhas ou peritos, de outras pessoas que possam lançar luz sobre os fatos" (art. 8. 2, “f”), respectivamente.

O Código de Processo Penal, por sua vez, garante, em diversos momentos, o direito à prova. Assim, por exemplo, o art. $159, \S 5 .^{\circ}$, permite às partes requererem a oitiva de peritos para esclarecimento acerca da prova ou responderes aos quesitos apresentados; o art. 41, 396-A e 406, $\S 3^{\circ}$, possibilita a indicação de provas pela acusação e defesa na fase do oferecimento e recebimento da denúncia; o art. 402 faculta a possibilidade de requerer-se diligências complementares após o final da instrução no procedimento ordinário etc.

A prova tem, pois, no processo em geral, o papel de, a partir da reconstrução dos fatos, conduzir o juiz a prolação de uma decisão final, analisando às pretensões entabuladas pelas partes ${ }^{5}$. É por isso que, ao analisar o direito à prova, ser possível notar uma estreita relação entre os direitos de ação e os direitos de defesa, não fazendo sentido assegurá-la, se não fosse oportunizado às partes a possibilidade de desenvolverem suas alegações ao longo do curso processual ${ }^{6}$. Em síntese, o

\footnotetext{
${ }^{2}$ SILVA, Marco Antonio Marques da. Igualdade na persecução criminal: investigação e produção de provas nos limites constitucionais. In: SILVA, Marco Antonio Marques da. (Org.). Processo penal e garantias constitucionais. 1. ed. São Paulo: Quartier Latin, 2006. p. 470.

${ }^{3}$ Nesse sentido, reconhecendo o direito à prova como consequência do devido processo legal, o Supremo Tribunal Federal já se pronunciou no sentido de que "assiste, ao interessado, mesmo em procedimentos de índole administrativa, como direta emanação da própria garantia constitucional do 'due process of law' (CF, art. 5', LIV) independentemente, portanto, de haver previsão normativa nos estatutos que regem a atuação dos órgãos do Estado -, a prerrogativa indisponível do contraditório e da plenitude de defesa, com os meios e recursos a ela inerentes (CF, art. $\left.5^{\circ}, \mathrm{LV}\right)$. - Abrangência da cláusula constitucional do 'due process of law', que compreende, dentre as diversas prerrogativas de ordem jurídica que a compõem, o direito à prova" (RMS n. ${ }^{\circ}$ 28.517-AgR/DF, $2^{\mathrm{a}}$ t., rel. Min. Celso de Mello, DJe 02/05/2014). Partilhando desse posicionamento, cf. BADARÓ, Gustavo Henrique Righi Ivahy. Um modelo de epistemologia judiciária: o controle lógico e racional do juízo de fato no processo penal. 2018. Tese (Concurso de Professor Titular) - Faculdade de Direito, Universidade de São Paulo, São Paulo. p. 22.

${ }^{4}$ FURTADO, Régis Munari. Presunção de inocência e execução provisória da pena: evolução do tema no Supremo Tribunal Federal a partir da Constituição de 1988. 2019. Dissertação (Mestrado em Direito) - Faculdade de Direito, Pontifícia Universidade Católica de São Paulo, São Paulo. p. 113.

${ }^{5}$ BADARÓ, Gustavo Henrique Righi Ivahy. Um modelo de epistemologia judiciária: o controle lógico e racional do juízo de fato no processo penal. 2018. Tese (Concurso de Professor Titular) - Faculdade de Direito, Universidade de São Paulo, São Paulo. p. 19.

${ }^{6}$ FERNANDES, Antonio Scarance. Processo penal constitucional. 6. ed. São Paulo: RT, 2010. p. 73; AVOLIO, Luiz Francisco Torquato. Provas ilícitas: interceptações telefônicas, ambientais e gravações clandestinas. 5. ed. São Paulo: RT, 2012. p. 31. Em mesmo sentido, GRINOVER, Ada Pellegrini Grinover; FERNANDES, Antonio Scarance; GOMES FILHO, Antonio Magalhães (As nulidades no processo penal. 9. ed. São Paulo: RT, 2006. p. 137), assentam que "o concreto exercício da ação e da defesa fica essencialmente subordinado à efetiva possibilidade de se representar Revista de Direito Brasileira | Florianópolis, SC | v. 26 | n. 10 | p. 365-386 | Mai./Ago. 2020
} 
direito à prova, pode ser entendido, segundo Paolo Tonini como uma expressão "que compreende o direito de todas as partes de buscar as fontes de prova, requerer a admissão do respectivo meio, participar de sua produção e apresentar uma valoração no momento das conclusões"7.

É por isso que, ao analisar o direito à prova, ser dele possível extrair oito postulados, conforme Antonio Scarance Fernandes: o direito de requisição da prova em si, o direito a ver o juiz apreciando a prova produzida, o direito de, sendo deferida a prova, vê-la produzida, o direito à participação na produção da prova, o direito ao contraditório na produção da prova, o direito à produção da prova com a participação do juiz, o direito à manifestação após a realização da prova e, finalmente, o direito à avaliação da prova pelo juiz ${ }^{8}$.

Apesar de o direito à prova ter estatura constitucional, seja por força da Constituição Federal e das Convenções Internacionais de Direito Humanos, seja pela regulamentação infraconstitucional, é certo que tal não se constitui em direito absoluto ${ }^{9}$, sujeitando-se aos limites impostos por outros valores e interesses que o ordenamento jurídico também assegura proteção ${ }^{10}$. Implica dizer, portanto, que somente amparado em rígidos critérios morais, lógicos, psicológicos, éticos e jurídicos, a produção da prova poderá ser legitimada ao longo do curso processual ${ }^{11}$. Aliás, de acordo com Ada Pellegrini Grinover, Antonio Scarance Fernandes e Antonio Magalhães Gomes Filho,

É exatamente no processo penal, onde avulta a liberdade do indivíduo, que se torna mais nítida a necessidade de se colocarem limites à atividade instrutória. A dicotomia defesa social/direitos de liberdades assume frequentemente conotações dramáticas no juízo penal; e a obrigação de o Estado sacrificar na menor medida possível os direitos de personalidade do acusado transforma-se na pedra de toque de um sistema de liberdades públicas ${ }^{12}$.

Assim, são muitas as razões que implicam em deslegitimação na produção de determinada prova durante o trâmite da ação penal. A Constituição Federal foi, aliás, bastante generosa no reconhecimento de direitos e garantias fundamentais, podendo-se destacar, por exemplo, a inviolabilidade da intimidade, da vida privada, da honra e da imagem (art. 5. ${ }^{\circ}, \mathrm{X}^{13}$ ), a inviolabilidade de domicílio (art. $5^{\circ}, \mathrm{XI}^{14}$ ), a inviolabilidade do sigilo das comunicações telegráficas, de dados e das comunicações telefônicas (art. $5^{\circ}, \mathrm{XII}^{15}$ ), o direito ao silêncio (art. 5. ${ }^{\circ}$,

ao juiz a realidade do fato posto como fundamento das pretensões das partes, ou seja, de estas poderem servir-se das provas".

${ }^{7}$ TONINI, Paolo. A prova no processo penal italiano. São Paulo: RT, 2002. p. 83.

${ }^{8}$ FERNANDES, Antonio Scarance. Processo penal constitucional. 6. ed. São Paulo: RT, 2010. p. 73.

${ }^{9}$ GIACOMOLLI, José Nereu. O devido processo penal: abordagem conforme a Constituição Federal e o Pacto de São José da Costa Rica. São Paulo: Atlas, 2013. p. 164; BARROS, Marco Antonio de. A busca da verdade no processo penal. 2. ed. São Paulo: RT, 2010. p. 171; DEZEM, Guilherme Madeira. Curso de processo penal. São Paulo: RT, 2015. p. 422.

${ }^{10}$ GOMES FILHO, Antonio Magalhães. Direito à prova no processo penal. São Paulo: RT, 1997. p. 91.

${ }^{11}$ GOMES FILHO, Antonio Magalhães. Direito à prova no processo penal. São Paulo: RT, 1997. p. 92.

${ }^{12}$ GRINOVER, Ada Pellegrini Grinover; FERNANDES, Antonio Scarance; GOMES FILHO, Antonio Magalhães. As nulidades no processo penal. 9. ed. São Paulo: RT, 2006. p. 146.

${ }^{13}$ Art. 5. ${ }^{\circ}(\ldots)$. X - são invioláveis a intimidade, a vida privada, a honra e a imagem das pessoas, assegurado o direito a indenização pelo dano material ou moral decorrente de sua violação.

${ }^{14}$ Art. 5. ${ }^{\circ}($...). XI - a casa é asilo inviolável do indivíduo, ninguém nela podendo penetrar sem consentimento do morador, salvo em caso de flagrante delito ou desastre, ou para prestar socorro, ou, durante o dia, por determinação judicial.

15 Art. 5. ${ }^{\circ}$ (...). XII - é inviolável o sigilo da correspondência e das comunicações telegráficas, de dados e das comunicações telefônicas, salvo, no último caso, por ordem judicial, nas hipóteses e na forma que a lei estabelecer para fins de investigação criminal ou instrução processual penal.

Revista de Direito Brasileira | Florianópolis, SC | v. 26 | n. 10 | p. 365-386 | Mai./Ago. 2020 
LXIII $^{16}$ ), a vedação a tortura (art. 5. ${ }^{\circ}$, III $^{17}$ ), a garantia do sigilo a fonte jornalística (art. 5. ${ }^{\circ}$, XIV $^{18}$ ). Na legislação infraconstitucional, por sua vez, pode ser encontrado, por exemplo, a criminalização da violação da correspondência (art. $151^{19}$ do Código Penal), a divulgação de segredo (art. $153^{20}$ do Código Penal), a violação de segredo profissional (art. $154^{21}$ do Código Penal e art. $207^{22}$ do Código de Processo Penal), a invasão de dispositivo informático (art. 154-A ${ }^{23}$ do Código Penal), dentre outros diversos dispositivos que, dentre outras razões buscam proteger a intimidade das pessoas.

Em que pese a enorme quantidade de hipóteses que podem, por seu próprio teor, vir a restringir a produção de provas no processo penal, interessa-nos, considerando os enfoques dados ao presente trabalho, apenas a limitação probatória decorrente da inviolabilidade da intimidade, da vida privada, da honra e da imagem, o qual decorre não apenas da previsão constante no art. 5. $^{\circ}$, $\mathrm{X}$, da Constituição, mas também no art. $11^{24}$ do Pacto de São José da Costa Rica.

$\mathrm{O}$ direito à intimidade, enquanto garantia apta a efetivar a própria dignidade da pessoa humana $^{25}$, deve ser entendida, pois, na esteira de Gilmar Ferreira Mendes e Paulo Gustavo Gonet Branco, como a proteção "as conversações e os episódios ainda mais íntimos, envolvendo relações familiares e amizades mais próximas", não se confundindo, entretanto, com o direito à privacidade que, segundo tais autores, está ligado ao "comportamento e acontecimentos atinentes aos relacionamentos pessoais em geral, às relações comerciais e profissionais que o indivíduo não deseja que se espalhem"26. Para Ada Pellegrini Grinover,

${ }^{16}$ Art. 5..$^{\circ}(.$.$) . LXIII - o preso será informado de seus direitos, entre os quais o de permanecer calado, sendo-lhe$ assegurada a assistência da família e de advogado.

${ }^{17}$ Art. $5 .^{\circ}$ (...). III - ninguém será submetido a tortura nem a tratamento desumano ou degradante.

${ }^{18}$ Art. 5. ${ }^{\circ}($....). XIV - é assegurado a todos o acesso à informação e resguardado o sigilo da fonte, quando necessário ao exercício profissional.

${ }^{19}$ Art. 151. Devassar indevidamente o conteúdo de correspondência fechada, dirigida a outrem: Pena: detenção, de um a seis meses, ou multa.

${ }^{20}$ Art. 153. Divulgar alguém, sem justa causa, conteúdo de documento particular ou de correspondência confidencial, de que é destinatário ou detentor, e cuja divulgação possa produzir dano a outrem: Pena: detenção, de um a seis meses, ou multa, de trezentos mil réis a dois contos de réis.

${ }^{21}$ Art. 154. Revelar alguém, sem justa causa, segredo, de que tem ciência em razão de função, ministério, ofício ou profissão, e cuja revelação possa produzir dano a outrem: Pena: detenção, de três meses a um ano, ou multa de um conto a dez contos de réis.

${ }^{22}$ Art. 207. São proibidas de depor as pessoas que, em razão de função, ministério, ofício ou profissão, devam guardar segredo, salvo se, desobrigadas pela parte interessada, quiserem dar o seu testemunho.

${ }^{23}$ Art. 154-A. Invadir dispositivo informático alheio, conectado ou não à rede de computadores, mediante violação indevida de mecanismo de segurança e com o fim de obter, adulterar ou destruir dados ou informações sem autorização expressa ou tácita do titular do dispositivo ou instalar vulnerabilidades para obter vantagem ilícita. Pena: detenção, de três meses a um ano, e multa.

${ }^{24}$ Art. 11. Proteção da Honra e da Dignidade 1. Toda pessoa tem direito ao respeito de sua honra e ao reconhecimento de sua dignidade. 2. Ninguém pode ser objeto de ingerências arbitrárias ou abusivas em sua vida privada, na de sua família, em seu domicílio ou em sua correspondência, nem de ofensas ilegais à sua honra ou reputação. 3. Toda pessoa tem direito à proteção da lei contra tais ingerências ou tais ofensas.

${ }^{25}$ BARROS, Marco Antonio de. A busca da verdade no processo penal. 2. ed. São Paulo: RT, 2010. p. 179. Em mesmo sentido, observa SILVA, Marco Antonio Marques da (Cidadania e democracia: instrumentos para a efetivação da dignidade humana. In: MIRANDA, Jorge; SILVA, Marco Antonio Marques da. (Coords.). Tratado luso-brasileiro da dignidade humana. 2. ed. São Paulo: Quartier Latin, 2009. p. 224), que "a dignidade humana existe em todos os indivíduos e impõe o respeito mútuo entre as pessoas, no ato da comunicação, e se opõe a uma interferência indevida na vida privada pelo Estado. Tais direitos são inerentes, conhecidos pelas pessoas, não podendo, portanto, o Estado desconhecê-los. A este cabe, ainda, criar condições favoráveis para uma integral realização dos mesmos". Em sentido contrário, GRINOVER, Ada Pellegrini (Liberdades públicas e processo penal: as interceptações telefônicas. 2. ed. São Paulo: RT, 1982. p. 86) entende que ainda que o direito à intimidade "não seja entendido como pressuposto para a existência dos demais direitos da pessoa humana, integra indubitavelmente os direitos da personalidade".

${ }^{26}$ MENDES, Gilmar Ferreira; BRANCO, Paulo Gustavo Gonet. Curso de direito constitucional. 6. ed. São Paulo: Saraiva, 2011.p. 315.

Revista de Direito Brasileira | Florianópolis, SC | v. 26 | n. 10 | p. 365-386 | Mai./Ago. 2020 
A intimidade representa uma esfera de que o indivíduo necessita vitalmente para poder livre e harmoniosamente desenvolver sua personalidade, ao abrigo de interferências arbitrárias. Com base nesse conceito, o direito à intimidade há de ser reconhecido como fator primordial em qualquer sistema de liberdades públicas $^{27}$.

Daí a razão de, ainda que com a dificuldade inerente de precisar os limites e os âmbitos de proteção da vida íntima, defender Antonio Magalhães Gomes Filho, a ideia de que as intromissões a vida familiar, em nenhuma hipótese, devem justificar o interesse de obtenção da prova, tal qual, aliás, garante-se quanto à proteção dos segredos profissionais ${ }^{28}$.

A nós, parece que o direito à intimidade serve, no processo penal, como um mecanismo capaz de proteger o indivíduo contra ingerências arbitrárias do Estado, inadmitindo a sua relativização a não ser nos casos previstos pela Constituição e nas hipóteses expressamente disciplinadas pela legislação infraconstitucional pressupondo, a não ser em casos absolutamente justificados e remotíssimos, a atuação do Poder Judiciário.

Em outras palavras, a violação a intimidade somente pode ser legitimada, no que diz respeito a seus parâmetros, quando obedecidos três vetores: em situações de gravidade extrema que fujam das soluções habituais, seja indispensável para a atividade persecutória estatal e seja o único caminho possível de descoberta da verdade ${ }^{29}$. Desatendidos tais disposições, será inevitável reconhecer a ilicitude ou a ilegitimidade da prova obtida, a depender da hipótese e, pois, a sua imprestabilidade ao processo.

\section{PROVAS ILÍCITAS E ILEGÍTIMAS: TRATAMENTO CONSTITUCIONAL, LEGAL E O PRINCÍPIO DA PROPORCIONALIDADE}

Ao contrário do que eventualmente pode ser cogitado, o rito probatório não se trata de um mero formalismo inútil e vazio, desprovido de substância e de preceitos éticos. Na realidade, as regras probatórias nada mais são do que instrumentos garantidores colocados à disposição do Estado em favor do indivíduo e que, em última análise, constitui-se em tutela em favor da liberdade ${ }^{30}$.

O processo penal, como já tivemos a oportunidade de aduzir, constitui-se em mecanismo de controle do poder punitivo, protegendo a liberdade e, em última análise, materializando o princípio da dignidade da pessoa humana ${ }^{31}$. Isso significa, sem mais delongas, que o ser humano existe como um fim em si mesmo, jamais como um meio, impondo-se, em consequência, a ideia de que a dignidade humana como valor maior a orientar o constitucionalismo contemporâneo e,

\footnotetext{
${ }^{27}$ GRINOVER, Ada Pellegrini Grinover. Liberdades públicas e processo penal: as interceptações telefônicas. 2 . ed. São Paulo: RT, 1982. p. 87.

${ }^{28}$ GOMES FILHO, Antonio Magalhães. Direito à prova no processo penal. São Paulo: RT, 1997. p. 91.

${ }^{29}$ BARROS, Marco Antonio de. A busca da verdade no processo penal. 2. ed. São Paulo: RT, 2010. p. 180.

${ }^{30}$ RANGEL, Paulo. Direito processual penal. 22. ed. São Paulo: Atlas, 2014. p. 473; GRINOVER, Ada Pellegrini Grinover; FERNANDES, Antonio Scarance; GOMES FILHO, Antonio Magalhães. As nulidades no processo penal. 9. ed. São Paulo: RT, 2006. p. 147; GRINOVER, Ada Pellegrini. Liberdades públicas e processo penal: as interceptações telefônicas. 2. ed. São Paulo: RT, 1982. p. 93. Sobre o tema, escreve PACELLI, Eugênio (Curso de processo penal. 18. ed. São Paulo: Atlas, 2014. p. 345), que "a norma assecuratória da inadmissibilidade das provas obtidas com violação de direito, com efeito, presta-se, a um só tempo, a tutelar direitos e garantias individuais, bem como a própria qualidade do material probatório a ser introduzido e valorado no processo".

${ }^{31}$ Para RANGEL, Paulo (Direito processual penal. 22. ed. São Paulo: Atlas, 2014. p. 473), "no Estado Democrático de Direito os fins não justificam os meios. Não há como se garantir a dignidade da pessoa humana admitindo uma prova obtida com violação às normas legais em vigor. Do contrário, estaríamos em um Estado opressor, totalitário e não Democrático de Direito (cf. art. $1^{\circ}$ da CRFB)". Mais à frente, esse mesmo autor (op. cit., p. 482) argumenta, ao tratar das provas ilícitas, que "o preço de se viver em uma democracia não tolera esse tipo de prova colhida ao arrepio da lei. Do contrário, não vale a pena viver em um Estado Democrático de Direito".
}

Revista de Direito Brasileira | Florianópolis, SC | v. 26 | n. 10 | p. 365-386 | Mai./Ago. 2020 
mais especificamente, o processo penal ${ }^{32}$. Acerca disso, Marco Antonio Marques da Silva aponta que,

A dignidade da pessoa humana é o reconhecimento constitucional dos limites da esfera de intervenção do Estado na vida do cidadão e por essa razão os direitos fundamentais, no âmbito do poder do Estado, dela decorrem, determinando que a função judicial seja um fator relevante para conhecer-se o alcance real destes direitos. Ela decorre da própria natureza humana, o ser humano deve ser sempre tratado de modo diferenciado em face de sua natureza racional; o seu respeito não é uma concessão ao Estado, mas nasce da própria soberania popular, ligando-se a própria noção de Estado Democrático de Direito ${ }^{33}$.

Se é real a noção de que a verdade absoluta é inatingível no processo, tal hipótese não pode desvincular a ideia de que uma decisão justa somente será possível quando essa busca se legitimar ao longo do curso processual ${ }^{34}$. Justamente por isso, a prova ilícita acaba sendo objeto de intensa discussão, uma vez que ela acaba por aprofundar a dualidade estabelecida no processo entre a busca da verdade, de um lado e, do outro, a proteção de direitos e garantias individuais daquele submetido a persecução penal ${ }^{35}$.

Foi evidentemente a preocupação com a utilização das provas ilícitas no processo penal que, ao ser promulgada em 1988, a Constituição expressamente trouxe, em seu art. 5. ${ }^{\circ}$, LVI, a previsão pelo qual "são inadmissíveis, no processo, as provas obtidas por meios ilícitos". Regulando o tema na legislação infraconstitucional, a Lei n. ${ }^{\circ} 11.690 / 2008$, ao alterar o art. 157 do Código de Processo Penal, deu nova redação ao dispositivo, prevendo serem "inadmissíveis, devendo ser desentranhadas do processo, as provas ilícitas, assim entendidas as obtidas em violação a normas constitucionais ou legais".

É por isso que, do ponto de vista conceitual, alguns autores e autoras passaram a promover diferenciações entre "provas ilegais", "provas ilegítimas" e "provas ilícitas". Desse modo, enquanto as "provas ilegais", segundo Ada Pellegrini Grinover, amparada nos escritos de Pietro Nuvolone, manifestar-se-iam "toda vez que caracterizar violações de normas legais ou de princípios gerais do ordenamento, de natureza processual ou material", as "prova ilegítimas" se apresentariam "quando a proibição for colocada por uma lei processual", sendo, "provas ilícitas" "quando, pelo contrário, a proibição for de natureza material" 36 .

Apesar de tais nomenclaturas, contudo, entendemos que a diferenciação acaba perdendo a sua relevância quanto a análise da ilicitude em matéria probatória. Isso porque muito embora seja possível fazer uma diferenciação, para fins meramente didáticos, entre "provas ilícitas" e

${ }^{32}$ PIOVESAN, Flávia. Direitos humanos e o direito constitucional internacional. 12. ed. São Paulo: Saraiva, 2011. p. $81-83$.

${ }^{33}$ SILVA, Marco Antonio Marques da. Refugiados são pessoas, dignas e com direitos. In: PINTO, Eduardo VeraCruz; PERAZZOLO, José Rodolpho; BARROSO, Luís Roberto; SILVA, Marco Antonio Marques da; CICCO, Maria Cristina de. (Coords.). Refugiados, imigrantes e igualdade dos povos: estudos em homenagem a António Guterres. São Paulo: Quartier Latin, 2017. p. 956.

${ }^{34}$ BADARÓ, Gustavo Henrique Righi Ivahy. Ônus da prova no processo penal. São Paulo: RT, 2003. p. $25-26$.

${ }^{35}$ GRINOVER, Ada Pellegrini Grinover; FERNANDES, Antonio Scarance; GOMES FILHO, Antonio Magalhães. As nulidades no processo penal. 9. ed. São Paulo: RT, 2006. p. 148-149.

${ }^{36}$ GRINOVER, Ada Pellegrini. Liberdades públicas e processo penal: as interceptações telefônicas. 2. ed. São Paulo: RT, 1982. p. 98. Em mesmo sentido, acolhendo essa diferenciação: FERNANDES, Antonio Scarance. Processo penal constitucional. 6. ed. São Paulo: RT, 2010. p. 81-82; AVOLIO, Luiz Francisco Torquato. Provas ilícitas: interceptações telefônicas, ambientais e gravações clandestinas. 5. ed. São Paulo: RT, 2012. p. 43; BARROS, Marco Antonio de. A busca da verdade no processo penal. 2. ed. São Paulo: RT, 2010. p. 174; PEDROSO, Fernando de Almeida. Processo penal. O direito de defesa: repercussão, amplitude e limites. 3. ed. São Paulo: RT, 2001. p. 400401; DEZEM, Guilherme Madeira. Curso de processo penal. São Paulo: RT, 2015. p. 423; FEITOZA, Denilson. Direito processual penal: teoria, crítica e práxis. 5. ed. Niterói: Impetus, 2008. p. 605-607; RANGEL, Paulo. Direito processual penal. 22. ed. São Paulo: Atlas, 2014. p. 475.

Revista de Direito Brasileira | Florianópolis, SC | v. 26 | n. 10 | p. 365-386 | Mai./Ago. 2020 
"ilegítimas", a Constituição Federal simplesmente previu não admitir as provas obtidas por meios ilícitos, enquanto o Código de Processo Penal, ao tratar dessa matéria, entendeu como ilícitas todas aquelas provas obtidas "violação a normas constitucionais ou legais". Desse modo, seja a prova obtida com violação ao regramento processual, espécie, pois, de norma legal, seja com desrespeito a disposição constitucional, a consequência para ambas, ao final e ao cabo, acaba sendo a mesma: a impossibilidade de valoração do material produzido pelo magistrado e a sua utilização no processo $^{37}$.

Tendo em vista, no entanto, o já consolidado entendimento na doutrina nacional, em promover a distinção entre "provas ilícitas" e "provas ilegítimas", impõe-se registrar, no tocante à sanção processual, que duas têm sido as consequências da produção de uma ou de outra, muito embora, reitere-se, a consequência prática da produção de ambas seja a mesma: a vedação a sua valoração. Assim, enquanto na prova ilícita o efeito será a sua inadmissibilidade no processo, implicando, inclusive, em seu desentranhamento dos autos ${ }^{38}$, a prova ilegítima implicará na nulidade do que foi produzido ${ }^{39}$. Entretanto, como já acentuado, muito embora haja essa diferenciação, o art. 157, caput, do Código de Processo Penal impõe que tais provas, ilícitas ou ilegitimamente obtidas, sejam desentranhadas do processo.

Questão igualmente atinente a matéria, a possibilidade de utilização da prova ilícita mediante a aplicação do princípio da proporcionalidade, tem sido objeto de intensa discussão. Sobre a admissibilidade da prova ilícita, quatro correntes se manifestam, segundo Antonio Scarance Fernandes. A primeira, diz o autor, defende a admissibilidade da prova ilícita sempre que inexistir proibição na lei processual, punindo-se, quando o caso, o responsável pela prova mediante a prática de crime. A segunda, por sua vez, assenta, diante da unidade do sistema jurídica, a impossibilidade de utilização da prova ilícita, vedada tanto pela lei processual, quanto pela Constituição. A terceira, aponta ser inadmissível a prova que tenha sido obtida com desrespeito a própria Constituição, uma vez que tal prova seria, por consequência, igualmente inconstitucional.

\footnotetext{
${ }^{37}$ Muito embora não negue a distinção entre "provas ilícitas" e "provas ilícitas", BADARÓ, Gustavo Henrique Righi Ivahy (Processo penal. 4. ed. São Paulo: RT, 2016. p. 412), defende que "podem ser definidas como provas ilícitas as provas obtidas, admitidas ou produzidas com violação das garantias constitucionais, sejam as que asseguram liberdades públicas, sejam as que estabelecem garantias processuais". Em abono a essa posição, PACELLI, Eugênio e FISCHER, Douglas (Comentários ao Código de Processo Penal e sua jurisprudência. 4. ed. São Paulo: Atlas, 2012. p. 328) também não observa diferença entre "provas ilícitas" e "provas ilegítimas". Essa também é a posição de MORAES, Maurício Zanoide de (Presunção de inocência no processo penal brasileiro: análise de sua estrutura normativa para a elaboração legislativa e para a decisão judicial. Rio de Janeiro: Lumen Juris, 2010. p. 463, n. 341): "Para além da clássica divisão de provas ilegais em provas ilícitas (violadoras de normas constitucionais ou de direito material) e provas ilegítimas (violadoras de normas processuais), o legislador aceitou o conceito amplo de prova ilícita, determinando que qualquer violação a norma constitucional ou legal (material ou processual) gera a ilicitude da prova e, por força constitucional, a sua inadmissibilidade (art. 5. ${ }^{\circ}$, inciso LVI, CR) e, caso inserida nos autos, seja desentranhada”. Para ele, "o nosso CPP não contemplou essa distinção. Afirma serem inadmissíveis as provas ilícitas, assim entendidas as obtidas em violação a normas constitucionais ou legais (art. 157, CPP”. Na doutrina estrangeira, inserindo dentro da categoria de provas ilícitas tanto aquelas obtidas com violação a norma legal ou à Constituição, DEU, Teresa Armenta (La prueba ilícita: un estudio comparado. 2. ed. Madrid: Marcial Pons, 2011. p. 34) anota que "la ilicitud de la prueba puede provenir de distintas causas: ser pruebas legal y expresamente prohibidas, ser irregulares o resultar defectuosas, diversificándose la prohibición en virtud de su objeto (prohibición de prestar testimonio para quienes están obligados a guardar secreto); afectar a determinados métodos de investigación (torturas, coacciones o amenazas); referirse a determinados medios de prueba (testimonio entre parientes; testimonios de referencia); violentar derechos fundamentales; ser irregulares o resultar defectuosas. Puede producirse en diferentes momentos (antes o en el mismo proceso); operar en beneficio del causante de la ilicitud o de un tercero, o finalmente, consistir en actuaciones de diferentes sujetos (acusadores o acusado)".

${ }^{38}$ GRINOVER, Ada Pellegrini Grinover; FERNANDES, Antonio Scarance; GOMES FILHO, Antonio Magalhães. As nulidades no processo penal. 9. ed. São Paulo: RT, 2006. p. 161; FERNANDES, Antonio Scarance. Processo penal constitucional. 6. ed. São Paulo: RT, 2010. p. 91; DEZEM, Guilherme Madeira. Curso de processo penal. São Paulo: RT, 2015. p. 427.

${ }^{39}$ BADARÓ, Gustavo Henrique Righi Ivahy. Processo penal. 4. ed. São Paulo: RT, 2016. p. 408; DEZEM, Guilherme Madeira. Curso de processo penal. São Paulo: RT, 2015. p. 427.
}

Revista de Direito Brasileira | Florianópolis, SC | v. 26 | n. 10 | p. 365-386 | Mai./Ago. 2020 
E a quarta e última, entende possível a admissibilidade da prova ilícita, com fundamento na proporcionalidade, sempre que a sua utilização se justificar diante da proteção de elementos mais importantes do que aquele violado para a produção da prova ${ }^{40}$.

Em que pese as inúmeras correntes, nos interessa apenas uma: a legitimação da prova ilícita com fundamento na proporcionalidade. De acordo com Paulo Bonavides, o princípio da proporcionalidade deve ser entendido "pelo fato de presumir a existência de relação adequada entre um ou vários fins determinados e os meios com que são levados a cabo" 41 ou ainda, nas palavras de Nicolas Gonzalez-Cuellar Serrano, cuida-se a proporcionalidade "de um princípio geral do Direito que, em um sentido mais amplo, obriga o operador jurídico a tratar de alcançar o justo equilíbrio entre os interesses em conflito" ${ }^{42}$. Sua aplicação exige, pois, o atendimento a três vetores: a adequação ou idoneidade, a necessidade e a proporcionalidade em sentido estrito ${ }^{43}$.

O primeiro requisito, a adequação ou idoneidade, deve ser verificada ao se analisar se a restrição a determinado direito mostrar-se idôneo a atingir determinado resultado. $\mathrm{O}$ segundo, a necessidade, apresenta-se quando o meio utilizado é necessário para a consecução do objetivo almejado. O terceiro e último elemento, a proporcionalidade em sentido estrito, impõe seja observado qual valor em conflito merece prevalecer, se aquele atinente à proteção da liberdade individual ou, se por outro lado, a medida restritiva ${ }^{44}$. Desse modo, segundo os adeptos da utilização da prova ilícita com amparo na proporcionalidade, a sua aplicabilidade seria promovida caso a caso, sopesando o juiz as normas em conflito, a fim de verificar se a eventual proteção à utilização da prova ilícita não seria inferior, em termos e valores, àquela em que se estaria violando $^{45}$.

${ }^{40}$ FERNANDES, Antonio Scarance. Processo penal constitucional. 6. ed. São Paulo: RT, 2010. p. 82.

${ }^{41}$ BONAVIDES, Paulo. Curso de direito constitucional. 26. ed. São Paulo: Malheiros, 2011. p. 393. Diz o autor (op. cit., p. 395), outrossim, que "a vinculação do princípio da proporcionalidade ao Direito Constitucional ocorre por via dos direitos fundamentais. É aí que ele ganha extrema importância e aufere um prestígio e difusão tão larga quanto outros princípios cardeais e afins, nomeadamente o princípio da igualdade. Protegendo, pois, a liberdade, ou seja, amparando os direitos fundamentais, o princípio da proporcionalidade entende principalmente, como disse Zimmerli, como problema de limitação do poder legítimo, devendo fornecer o critério das limitações à liberdade individual".

42 SERRANO, Nicolas Gonzalez-Cuellar. Proporcionalidad y derechos fundamentales en el proceso penal. Madrid: Colex, 1990. p. 17.

${ }^{43}$ D'URSO, Flávia. Princípio constitucional da proporcionalidade no processo penal. São Paulo: Atlas, 2007. p. 102; PACHECO, Denilson Feitoza. O princípio da proporcionalidade no direito processual penal brasileiro. Rio de Janeiro: Lumen Juris, 2007. p. 248-263; RANGEL, Paulo. Direito processual penal. 22. ed. São Paulo: Atlas, 2014. p. 767; FERNANDES, Antonio Scarance. Processo penal constitucional. 6. ed. São Paulo: RT, 2010. p. $52-$ 54; MORAES, Maurício Zanoide de. Presunção de inocência no processo penal brasileiro: análise de sua estrutura normativa para a elaboração legislativa e para a decisão judicial. Rio de Janeiro: Lumen Juris, 2010. p. 312-313; ALEXY, Robert. Teoria dos direitos fundamentais. 2. ed. São Paulo: Malheiros, 2015. p. 116-117.

${ }^{44}$ D’URSO, Flávia. Princípio constitucional da proporcionalidade no processo penal. São Paulo: Atlas, 2007. p. 102; PACHECO, Denilson Feitoza. O princípio da proporcionalidade no direito processual penal brasileiro. Rio de Janeiro: Lumen Juris, 2007. p. 248-263; RANGEL, Paulo. Direito processual penal. 22. ed. São Paulo: Atlas, 2014. p. 767; FERNANDES, Antonio Scarance. Processo penal constitucional. 6. ed. São Paulo: RT, 2010. p. 5254; MORAES, Maurício Zanoide de. Presunção de inocência no processo penal brasileiro: análise de sua estrutura normativa para a elaboração legislativa e para a decisão judicial. Rio de Janeiro: Lumen Juris, 2010. p. 323-329; ALEXY, Robert. Teoria dos direitos fundamentais. 2. ed. São Paulo: Malheiros, 2015. p. 117-120.

${ }^{45}$ FERNANDES, Antonio Scarance. Processo penal constitucional. 6. ed. São Paulo: RT, 2010. p. 82. Ainda que sem mencionar a proporcionalidade, GRECO FILHO, Vicente (Manual de processo penal. 10. ed. São Paulo: Saraiva, 2013. p. 215) anota que, muito embora o texto constitucional aparentemente não admita qualquer prova obtida por meios ilícitos, tal regra não seria absoluta, "porque nenhuma regra constitucional é absoluta, uma vez que tem de conviver com outras regras ou princípios também constitucionais. Assim, continuará a ser necessário o confronto ou peso entre os bens jurídicos, desde que constitucionalmente garantidos, a fim de se admitir, ou não, a prova obtida por meio ilícito". Na doutrina estrangeira, SERRANO, Nicolas Gonzalez-Cuellar (Proporcionalidad y derechos fundamentales en el proceso penal. Madrid: Colex, 1990. p. 339-340), defende que "parece más conveniente inclinarse por una opción intermedia que trate de conciliar los intereses en conflicto desde la perspectiva del principio de proporcionalidad”. Seguindo essa orientação, GÖSSEL, Karl Heinz (As proibições de prova no direito processual penal da República Federal da Alemanha. Revista Portuguesa de Ciência Criminal. Coimbra, v. 2, n. 3, jul./set. Revista de Direito Brasileira | Florianópolis, SC | v. 26 | n. 10 | p. 365-386 | Mai./Ago. 2020 
Com o devido respeito a essa posição, tal qual já se manifestou o Supremo Tribunal Federal em mais de uma oportunidade, filiamo-nos a corrente que entende pela impossibilidade de utilização das provas ilícitas mediante a aplicação do princípio da proporcionalidade ${ }^{46}$. Isso porque, dificilmente seria possível prever uma hipótese no qual os vetores da adequação ou da idoneidade ou a necessidade, pudessem ser justificados, a fim de amparar uma eventual condenação criminal ${ }^{47}$. Assim, por exemplo, parece-nos inaceitável que uma prova obtida mediante tortura pudesse ser utilizada em favor do órgão acusador, tendo em vista a manifesta ausência de adequação ou idoneidade da medida, ou mesmo de necessidade, tal qual exigido pela proporcionalidade.

Hipótese, entretanto, diversa e que tem sido acolhido pela doutrina de forma quase pacífica $^{48}$, é a admissibilidade da utilização de prova ilícita em favor do acusado ou da acusada. Muito embora haja quem defenda tratar-se de hipótese ligada diretamente ao princípio da proporcionalidade ${ }^{49}$, entendemos que a sua justificação se encontra não só na proporcionalidade ${ }^{50}$, mas, sobretudo, na garantia da presunção de inocência (art. 5. ${ }^{\circ}$ LVII ${ }^{51}$, da Constituição Federal), uma vez que a prova da inocência do acusado ou da acusada deve sempre ser empregada em seu

1992, p. 424), aponta que “a intromissão nesta outra área da vida privada (para além da área nuclear) só será admissível 'em nome de interesses prevalecentes da comunidade e pressuposta a estrita observância do imperativo da proporcionalidade",.

46 Sobre o tema, aliás: “Objeção de princípio - em relação à qual houve reserva de Ministros do Tribunal - à tese aventada de que à garantia constitucional da inadmissibilidade da prova ilícita se possa opor, com o fim de dar-lhe prevalência em nome do princípio da proporcionalidade, o interesse público na eficácia da repressão penal em geral ou, em particular, na de determinados crimes: é que, aí, foi a Constituição mesma que ponderou os valores contrapostos e optou - em prejuízo, se necessário da eficácia da persecução criminal - pelos valores fundamentais, da dignidade humana, aos quais serve de salvaguarda a proscrição da prova ilícita: de qualquer sorte - salvo em casos extremos de necessidade inadiável e incontornável - a ponderação de quaisquer interesses constitucionais oponíveis à inviolabilidade do domicílio não compete a posteriori ao juiz do processo em que se pretenda introduzir ou valorizar a prova obtida na invasão ilícita, mas sim àquele a quem incumbe autorizar previamente a diligência" (HC n. ${ }^{\circ}$ 79.512/RJ, Pleno, rel. Min. Sepúlveda Pertence, DJ 16/05/2003). Em mesmo sentido: "Da explícita proscrição da prova ilícita, sem distinções quanto ao crime objeto do processo $\left(\mathrm{CF}\right.$, art. $\left.5^{\circ}, \mathrm{LVI}\right)$, resulta a prevalência da garantia nela estabelecida sobre o interesse na busca, a qualquer custo, da verdade real no processo: consequiente impertinência de apelar-se ao princípio da proporcionalidade - à luz de teorias estrangeiras inadequadas à ordem constitucional brasileira - para sobrepor, à vedação constitucional da admissão da prova ilícita, considerações sobre a gravidade da infração penal objeto da investigação ou da imputação" (HC n. ${ }^{\circ} 80.949 / R J, 1^{a}$ t., rel. Min. Sepúlveda Pertence, DJ 14/12/2001). ${ }^{47}$ DEZEM, Guilherme Madeira. Curso de processo penal. São Paulo: RT, 2015. p. 433. Essa posição é igualmente defendida, ainda que pelo acréscimo de outras razões, por GOMES FILHO, Antonio Magalhães (Direito à prova no processo penal. São Paulo: RT, 1997. p. 106) para quem, a admissão da proporcionalidade conduziria a uma disparidade de tratamento entre acusação e réu, bem como "a uma sistemática violação da presunção de inocência dos acusados de infrações mais graves, pois à simples imputação já se seguiriam efeitos negativos, não só no âmbito do processo, mas, igualmente, no campo dos direitos constitucionais protegidos pelas proibições de prova".

${ }^{48}$ PACELLI, Eugênio. Curso de processo penal. 11. ed. São Paulo: Atlas, 2014. p. 373-379; AVOLIO, Luiz Francisco Torquato. Provas ilícitas: interceptações telefônicas, ambientais e gravações clandestinas. 5. ed. São Paulo: RT, 2012. p. 66; RANGEL, Paulo. Direito processual penal. 22. ed. São Paulo: Atlas, 2014. p. 486-493; GRINOVER, Ada Pellegrini Grinover; FERNANDES, Antonio Scarance; GOMES FILHO, Antonio Magalhães. As nulidades no processo penal. 9. ed. São Paulo: RT, 2006. p. 153; Para GOMES FILHO, Antonio Magalhães. Direito à prova no processo penal. São Paulo: RT, 1997. p. 107; D’URSO, Flávia. Princípio constitucional da proporcionalidade no processo penal. São Paulo: Atlas, 2007. p. 124; GRINOVER, Ada Pellegrini. Liberdades públicas e processo penal: as interceptações telefônicas. 2. ed. São Paulo: RT, 1982. p. 151.

${ }^{49}$ FERNANDES, Antonio Scarance. Processo penal constitucional. 6. ed. São Paulo: RT, 2010. p. 82.

${ }^{50}$ Um dos críticos dessa posição é PACELLI, Eugênio (Curso de processo penal. 11. ed. São Paulo: Atlas, 2014 . p. 375) que entende pela impossibilidade de fixação da proporcionalidade como critério para admissibilidade das provas ilícitas, uma vez ser impossível "de se fixar qualquer critério minimamente objetivo para o aproveitamento da prova ilícita".

${ }^{51}$ Art. 5. ${ }^{\circ}$. (...) LVII - ninguém será considerado culpado até o trânsito em julgado de sentença penal condenatória. Revista de Direito Brasileira | Florianópolis, SC | v. 26 | n. 10 | p. 365-386 | Mai./Ago. 2020 
favor $^{52}$, sob pena de subversão da própria ideia de Estado Democrático de Direito e do respeito à dignidade da pessoa humana ${ }^{53}$.

Em todo caso, obtendo o acusado ou a acusada as provas que demonstrem a sua inocência por meios ilícitos, estará o indivíduo resguardado pelas causas excludentes de antijuridicidade (art. $23^{54}$ do Código Penal), afastando a impossibilidade utilização da prova ${ }^{55}$. Seria ilógico, segundo nos consta, admitir-se a vedação à utilização da prova ilícita, garantia individual reconhecida constitucionalmente, em desfavor daquele a quem a própria Constituição Federal quis proteger: o acusado $^{56}$. Até porque, segundo Manuel da Costa Andrade, "o princípio do Estado de Direito reclama a garantia e efectivação do bem jurídico individual face a actividade de perseguição do Estado" $" 57$. A aplicação proporcionalidade, portanto, somente se justifica se utilizada em favor do acusado ou da acusada.

\section{PROVAS ILÍCITAS POR DERIVAÇÃO OU A TEORIA DOS FRUTOS DA ÁRVORE ENVENENADA}

Matéria controvertida até as modificações advindas com a Lei n ${ }^{\circ} 11.690$, de 9 de junho de 2008, que alterou o Código de Processo Penal, a questão das provas ilícitas por derivação ou da teoria dos frutos da árvore envenenada gerava uma série de problemas ${ }^{58}$, sendo seu tratamento defendido em discussões doutrinárias e jurisprudenciais, em vista da inexistência de regramento

\footnotetext{
52 PACELLI, Eugênio. Curso de processo penal. 11. ed. São Paulo: Atlas, 2014. p. 376. Para GOMES FILHO, Antonio Magalhães (Direito à prova no processo penal. São Paulo: RT, 1997. p. 106-107), a admissibilidade da prova ilícita em favor do réu deve prevalecer "não só porque a liberdade e a dignidade da pessoa humana constituem valores insuperáveis na ótica da sociedade democrática, mas também porque o próprio Estado não pode interessar a punição do inocente, o que poderia significar a impunidade do verdadeiro culpado”. Em mesmo sentido, D’URSO, Flávia (Princípio constitucional da proporcionalidade no processo penal. São Paulo: Atlas, 2007. p. 122) assenta que "a ponderação de interesses encontra no princípio absoluto da dignidade da pessoa humana o seu limite". Por sua vez, MENDES, Gilmar Ferreira; BRANCO, Paulo Gustavo Gonet (Curso de direito constitucional. 6. ed. São Paulo: Saraiva, 2011. p. 596) entendem que "o princípio do devido processo legal, em sua face atinente à ampla defesa, autoriza a produção de provas ilícitas pro reo".

53 Para AVOLIO, Luiz Francisco Torquato (Provas ilícitas: interceptações telefônicas, ambientais e gravações clandestinas. 5. ed. São Paulo: RT, 2012. p. 217), "ao admitir-se a oponibilidade do direito à prova às liberdades públicas, indiscriminadamente, estar-se-ia criando um perigoso precedente para a liberdade a dignidade da pessoa humana: não se poderia mais estabelecer qualquer vedação probatória - todas as provas, ainda que ilícitas, seriam utilizáveis em nome do direito à prova, do atingimento da verdade real”. Na doutrina estrangeira: SIEGERT, Karl. I limiti di legalità delle registrazioni e riproduzioni magnetofoniche effettuate nel processo penale. Rivista italiana di diritto e procedura penale, Milano, v. 4, n. 3, jul./set. 1957, p. 499.

${ }^{54}$ Art. 23. Não há crime quando o agente pratica o fato: I - em estado de necessidade; II - em legítima defesa; III - em estrito cumprimento de dever legal ou no exercício regular de direito.

${ }^{55}$ RANGEL, Paulo. Direito processual penal. 22. ed. São Paulo: Atlas, 2014. p. 487; PACELLI, Eugênio. Curso de processo penal. 11. ed. São Paulo: Atlas, 2014. p. 376; GRINOVER, Ada Pellegrini Grinover; FERNANDES, Antonio Scarance; GOMES FILHO, Antonio Magalhães. As nulidades no processo penal. 9. ed. São Paulo: RT, 2006. p. 153. Há quem, no entanto, critique essa ideia, sugerindo a sua inaplicabilidade em determinados casos. Segundo DEZEM, Guilherme Madeira (Curso de processo penal. São Paulo: RT, 2015. p. 434), "a causa excludente da ilicitude, seja ela a legítima defesa, seja ela o estado de necessidade, não admite o sacrifício do bem de maior valor em detrimento do de menor valor".

${ }^{56}$ PACELLI, Eugênio. Curso de processo penal. 11. ed. São Paulo: Atlas, 2014. p. 376; MENDES, Gilmar Ferreira; BRANCO, Paulo Gustavo Gonet. Curso de direito constitucional. 6. ed. São Paulo: Saraiva, 2011. p. 596.

${ }^{57}$ ANDRADE, Manuel da Costa. Sobre as proibições de prova em processo penal. Coimbra: Coimbra Editora, 1992. p. 33.

${ }^{58}$ RANGEL, Paulo. Direito processual penal. 22. ed. São Paulo: Atlas, 2014. p. 476; GIACOMOLLI, José Nereu. O devido processo penal: abordagem conforme a Constituição Federal e o Pacto de São José da Costa Rica. São Paulo: Atlas, 2013. p. 167.
}

Revista de Direito Brasileira | Florianópolis, SC | v. 26 | n. 10 | p. 365-386 | Mai./Ago. 2020 
próprio $^{59}$. Questionava, assim, se a aquisição de provas lícitas, obtidas por meio das ilícitas, poderiam, ou não, ser aproveitada no curso do processo ${ }^{60}$.

O Plenário do Supremo Tribunal Federal, por exemplo, antes mesmo da reforma em questão, já se manifestava no sentido de que "as provas obtidas por meios ilícitos contaminam as que são exclusivamente delas decorrentes" ${ }^{\prime 61}$. Em outra oportunidade, a $2^{\mathrm{a}}$ Turma do Excelso Pretório manifestou-se no sentido de que a teoria dos frutos da árvore envenenada comprometia a produção das provas derivadas, uma vez que "não obstante produzidos, validamente, em momento ulterior, acham-se afetados, no entanto, pelo vício (gravíssimo) da ilicitude originária, que a eles se transmite, contaminando-os, por efeito de repercussão causal"62.

Com a reforma legislativa, incluiu-se no art. 157 do Código de Processo Penal, os $\S \S 1 .^{\circ}$ e 2. ${ }^{\circ}$, dispondo que, para além na inadmissibilidade das provas ilícitas, "são também inadmissíveis as provas derivadas das ilícitas, salvo quando não evidenciado o nexo de causalidade entre umas e outras, ou quando as derivadas puderem ser obtidas por uma fonte independente das primeiras", considerando-se "fonte independente aquela que por si só, seguindo os trâmites típicos e de praxe, próprios da investigação ou instrução criminal, seria capaz de conduzir ao fato objeto da prova", respectivamente.

No que diz respeito a primeira exceção, a ausência de nexo de causalidade entre uma prova e outra, cuida-se de uma medida inutilmente prevista pelo legislador ordinário, já que se entre a prova ilícita e as demais provas produzidas inexiste qualquer relação de causalidade, é de supor que as provas produzidas não guardam qualquer relação entre elas, não se podendo-lhe atribuir a pecha de prova ilícita ${ }^{63}$. Seja como for, é importante registrar competir ao órgão acusador, e não ao acusado ou acusada, o ônus de demonstrar que, entre uma prova ilícita e outra produzida no curso do processo, inexiste o nexo de causalidade ${ }^{64}$. A segunda hipótese, a fonte independente, por sua vez, apresenta-se quando, existindo duas fontes diversas, dos quais uma caminha para a ilicitude da prova e outra para a licitude, a prova não haverá de se ter por ilícita ${ }^{65}$, admitindo-a nos autos.

Com as alterações legislativas impostas no Código de Processo Penal por meio da Lei $n^{\circ}$ 11.690, de 9 de junho de 2008, entretanto, ficou finalmente superada a discussão da admissibilidade das provas ilícitas por derivação, tal qual já vinha manifestando o Supremo Tribunal Federal em algumas decisões. Ainda que com alguma imprecisão conceitual no tocante às hipóteses de

\footnotetext{
${ }^{59}$ BADARÓ, Gustavo Henrique Righi Ivahy. Processo penal. 4. ed. São Paulo: RT, 2016. p. 412.

${ }^{60}$ GRINOVER, Ada Pellegrini Grinover; FERNANDES, Antonio Scarance; GOMES FILHO, Antonio Magalhães. As nulidades no processo penal. 9. ed. São Paulo: RT, 2006. p. 153. Grande parte da discussão outrora existente acerca da inadmissibilidade da aplicação da teoria dos frutos da árvore envenenada, segundo AVOLIO, Luiz Francisco Torquato (Provas ilícitas: interceptações telefônicas, ambientais e gravações clandestinas. 5. ed. São Paulo: RT, 2012. p. 73), pelo fato de que "a Constituição deixou em aberto a questão da admissibilidade das provas ilícitas por derivação". Entretanto, segundo o autor, pouco importava as modificações, ou não, advindas com a lei ordinária, já que "estamos diante da ponte - antes extraída do sistema constitucional e ora inserida textualmente na Constituição que possibilita deduzir a inadmissibilidade processual a partir da ilicitude". Em que pese esse posicionamento, contudo, entendemos que a modificação advinda com a Lei no 11.690, de 9 de junho de 2008 foi, sim, bastante útil, uma vez que consolidou de uma vez por todas a inadmissibilidade da prova ilícita por derivação, a não ser nas hipóteses expressamente previstas nos $\S \S 1 .^{\circ}$ e $2 .^{\circ}$ do art. 157 do Código de Processo Penal.

${ }^{61} \mathrm{HC}$ n. ${ }^{\circ}$ 72.588/PB, Pleno, rel. Min. Maurício Corrêa, DJ 04/08/2000.

${ }^{62}$ RHC n. ${ }^{\circ}$ 90.376/RJ, $2^{\mathrm{a}}$ t., rel. Min. Celso de Mello, DJe 18/05/2007.

${ }^{63}$ BADARÓ, Gustavo Henrique Righi Ivahy. Processo penal. 4. ed. São Paulo: RT, 2016. p. 413; DEZEM, Guilherme Madeira. Curso de processo penal. São Paulo: RT, 2015. p. 435; RANGEL, Paulo. Direito processual penal. 22. ed. São Paulo: Atlas, 2014. p. 485-486.

${ }^{64}$ GIACOMOLLI, José Nereu. O devido processo penal: abordagem conforme a Constituição Federal e o Pacto de São José da Costa Rica. São Paulo: Atlas, 2013. p. 169.

${ }^{65}$ DEZEM, Guilherme Madeira. Curso de processo penal. São Paulo: RT, 2015. p. 435; GIACOMOLLI, José Nereu. O devido processo penal: abordagem conforme a Constituição Federal e o Pacto de São José da Costa Rica. São Paulo: Atlas, 2013. p. 170; RANGEL, Paulo. Direito processual penal. 22. ed. São Paulo: Atlas, 2014. p. 485-486.

Revista de Direito Brasileira | Florianópolis, SC | v. 26 | n. 10 | p. 365-386 | Mai./Ago. 2020
} 
admissibilidade da prova ${ }^{66}$, a ausência de nexo causal entre uma prova e outra, bem assim a existência de fonte independente, a regulamentação estabeleceu as hipóteses na qual a prova derivada das ilícitas não será admitida.

\section{INTERCEPTAÇÕES E GRAVAÇÕES CLANDESTINAS: DISTINÇÕES NECESSÁRIAS}

Importa distinguir, então, a diferença entre gravações e interceptações, bem como temas ligados a essa nomenclatura, evitando-se eventuais confusões conceituais possíveis. Do ponto de vista jurídico, as interceptações, acolhendo a definição de Gilmar Ferreira Mendes e Paulo Gustavo Gonet Branco, pode ser entendida como "a captação da conversa realizada por um terceiro, com ou sem o conhecimento de um dos interlocutores"67.

É o caso, por exemplo, da interceptação telefônica ou do grampo telefônico, no qual, um terceiro, por meio da "interceptação do fluxo de comunicações em sistemas de informática e telemática" (art. 1. ${ }^{\circ}$, parágrafo único, da Lei n..$^{\circ}$ 9.296, de 24 de julho de 1996), passa a gravar a conversa que se estabelece entre os interlocutores, sem que estes detenham conhecimento da prática $^{68}$. Também é hipótese de interceptação, mas na modalidade ambiental, o terceiro que, em uma reunião, insere um gravador, sem o conhecimento dos participantes, para captar os diálogos ${ }^{69}$.

Por outro lado, as gravações clandestinas ${ }^{70}$ ou ambientais ${ }^{71}$ são aquelas, também na definição Gilmar Ferreira Mendes e Paulo Gustavo Gonet Branco, no qual "a captação da conversa é feita por um dos interlocutores, sem o conhecimento do outro"72. Seria a hipótese, por exemplo, no qual entre dois interlocutores ao telefone, um deles resolve gravar a conversa estabelecida entre

${ }^{66}$ Sobre o tema, não há como discordar de PACELLI, Eugênio (Curso de processo penal. 18. ed. São Paulo: Atlas, 2014. p. 364) a crítica, dirigida ao texto legislativo dos $\$ \S 1 .^{\circ}$ e $2 .^{\circ}$ do art. 157 do Código de Processo Penal, ao confundir a teoria da fonte independente com a teoria da descoberta inevitável. Isso porque, escreve o autor, ao definir "fonte independente", o legislador acabou por trazer "a definição de outra hipótese de aproveitamento da prova, qual seja, a teoria da descoberta inevitável, muito utilizada no direito estadunidense". Em contrapartida, "a teoria da fonte independente baseia-se precisamente na ausência fática da relação de causalidade ou de dependência lógica ou temporal (produção da prova posteriormente à ilícita)". Em mesmo sentido, DEZEM, Guilherme Madeira (Curso de processo penal. São Paulo: RT, 2015. p. 437) aponta que "embora o $\S 1 .^{\circ}$ do art. 157 permita a rápida leitura de que teria sido adotada a teoria da fonte independente (...), em verdade, fora positiva a teoria da descoberta inevitável, também chamada de exceção da fonte hipotética independente".

${ }^{67}$ MENDES, Gilmar Ferreira; BRANCO, Paulo Gustavo Gonet. Curso de direito constitucional. 6. ed. São Paulo: Saraiva, 2011. p. 597. Em mesmo sentido: FERNANDES, Antonio Scarance. Processo penal constitucional. 6. ed. São Paulo: RT, 2010. p. 92; BADARÓ, Gustavo Henrique Righi Ivahy. Processo penal. 4. ed. São Paulo: RT, 2016. p. 504.

68 STRECK, Lenio Luiz. As interceptações telefônicas e os direitos fundamentais: Constituição, cidadania, violência: a Lei 9.296/96 e seus reflexos penais e processuais. Porto Alegre: Livraria do Advogado, 1997. p. 87. Segundo GRINOVER, Ada Pellegrini Grinover; FERNANDES, Antonio Scarance; GOMES FILHO, Antonio Magalhães (As nulidades no processo penal. 9. ed. São Paulo: RT, 2006. p. 196), entretanto, "não desfigura a natureza da interceptação o fato de um dos interlocutores saber que ela está ocorrendo. Mas, para distinguir a hipótese de interceptação sem o conhecimento dos interlocutores daquela feita com a anuência de um deles, pode-se reservar a denominação de interceptação 'stricto sensu' à primeira, enquanto para a segunda se pode falar em escuta".

${ }^{69}$ GRINOVER, Ada Pellegrini Grinover; FERNANDES, Antonio Scarance; GOMES FILHO, Antonio Magalhães. As nulidades no processo penal. 9. ed. São Paulo: RT, 2006. p. 195-196; BADARÓ, Gustavo Henrique Righi Ivahy. Processo penal. 4. ed. São Paulo: RT, 2016. p. 504.

${ }^{70}$ SZANIAWSKI, Elimar. Direitos de personalidade e sua tutela. São Paulo: RT, 1993. p. 189.

${ }^{71}$ BADARÓ, Gustavo Henrique Righi Ivahy. Processo penal. 4. ed. São Paulo: RT, 2016. p. 504. É válida, no entanto, a distinção promovida por PACELLI, Eugênio (Curso de processo penal. 11. ed. São Paulo: Atlas, 2014. p. 347) que, ao analisar a gravação ambiental, assenta ser ela ser gênero, enquanto a gravação clandestina ou autorizada seriam espécies.

${ }^{72}$ MENDES, Gilmar Ferreira; BRANCO, Paulo Gustavo Gonet. Curso de direito constitucional. 6. ed. São Paulo: Saraiva, 2011. p. 597. Em mesmo sentido: FERNANDES, Antonio Scarance. Processo penal constitucional. 6. ed. São Paulo: RT, 2010. p. 92.

Revista de Direito Brasileira | Florianópolis, SC | v. 26 | n. 10 | p. 365-386 | Mai./Ago. 2020 
ambos, sem que o outro tenha conhecimento da captação ${ }^{73}$. Também seria o caso da captação subreptícia da conversa entre os presentes, sem que os demais tenham conhecimento de que a gravação esteja ocorrendo ${ }^{74}$.

Seja qual for a hipótese, tanto as interceptações, quanto as gravações clandestinas podem ser consideradas lícitas ou ilícitas ${ }^{75}$ e, como consequência, podem, ou não, implicar na ilicitude da prova eventualmente produzida. Uma interceptação telefônica promovida por um terceiro, mas realizada após prévia autorização judicial (art. 5. ${ }^{\circ}$, XII $^{76}$, da Constituição e art. 3. ${ }^{\text {o77 }}$ da Lei n. ${ }^{\circ}$ 9.296, de 24 de julho de 1996), em decisão devidamente fundamentada (art. 93, IX ${ }^{78}$, da Constituição) e nas hipóteses autorizadas pelo art. $2 .^{{ }^{779}}$ da Lei n. ${ }^{\circ}$ 9.296, de 24 de julho de 1996, certamente serão lícitas e poderão ser utilizadas regulamente no curso do processo. De igual modo, a interceptação ambiental realizada por terceiro sem que os presentes tenham conhecimento da captação, a depender do teor da conversa pode haver violação a intimidade, tornando a prova ilícita ${ }^{80}$.

Entretanto, uma gravação ambiental realizada por um dos interlocutores, de forma lícita, com o simples intuito de documentar a conversa travada entre aqueles, pode vir a tornar-se uma prova ilícita, a depender do contexto em que ela for empregada no processo, já que eventualmente pode ensejar em violação a privacidade (art. $5 .^{\circ}, \mathrm{X}$, da Constituição ${ }^{81}$ ), tornando a prova absolutamente imprestável para ser utilizada no contexto processual ${ }^{82}$. É justamente essa complexidade que levou o Supremo Tribunal Federal a analisar, por diversas vezes, a

\footnotetext{
${ }^{73}$ GRINOVER, Ada Pellegrini Grinover; FERNANDES, Antonio Scarance; GOMES FILHO, Antonio Magalhães. As nulidades no processo penal. 9. ed. São Paulo: RT, 2006. p. 195-196.

${ }^{74}$ GRINOVER, Ada Pellegrini Grinover; FERNANDES, Antonio Scarance; GOMES FILHO, Antonio Magalhães. As nulidades no processo penal. 9. ed. São Paulo: RT, 2006. p. 195-196.

${ }^{75}$ GRINOVER, Ada Pellegrini Grinover; FERNANDES, Antonio Scarance; GOMES FILHO, Antonio Magalhães. As nulidades no processo penal. 9. ed. São Paulo: RT, 2006. p. 195-196; PACELLI, Eugênio. Curso de processo penal.
} 11. ed. São Paulo: Atlas, 2014. p. 347.

${ }^{76}$ Art. 5. ${ }^{\circ}$. (...) XII - é inviolável o sigilo da correspondência e das comunicações telegráficas, de dados e das comunicações telefônicas, salvo, no último caso, por ordem judicial, nas hipóteses e na forma que a lei estabelecer para fins de investigação criminal ou instrução processual penal.

${ }^{77}$ Art. $3 .^{\circ}$ A interceptação das comunicações telefônicas poderá ser determinada pelo juiz, de ofício ou a requerimento: I - da autoridade policial, na investigação criminal; II - do representante do Ministério Público, na investigação criminal e na instrução processual penal.

${ }^{78}$ Art. 93. (...) IX - todos os julgamentos dos órgãos do Poder Judiciário serão públicos, e fundamentadas todas as decisões, sob pena de nulidade (...).

79 Art. 2. ${ }^{\circ}$ Não será admitida a interceptação de comunicações telefônicas quando ocorrer qualquer das seguintes hipóteses: I - não houver indícios razoáveis da autoria ou participação em infração penal; II - a prova puder ser feita por outros meios disponíveis; III - o fato investigado constituir infração penal punida, no máximo, com pena de detenção. Parágrafo único. Em qualquer hipótese deve ser descrita com clareza a situação objeto da investigação, inclusive com a indicação e qualificação dos investigados, salvo impossibilidade manifesta, devidamente justificada. ${ }^{80}$ GRINOVER, Ada Pellegrini Grinover; FERNANDES, Antonio Scarance; GOMES FILHO, Antonio Magalhães. As nulidades no processo penal. 9. ed. São Paulo: RT, 2006. p. 221. Na legislação infraconstitucional, a união regulamentação a tratar da interceptação ambiental é encontrada na Lei n. ${ }^{\circ} 12.850$, de 2 de agosto de 2013 que, além de ter finalmente conceituado organização criminosa (art. $1 .^{\circ}, \S 1 .^{\circ}$ ), estabeleceu a "captação ambiental de sinais eletromagnéticos, ópticos ou acústicos" como meio de obtenção de prova (art. 3. ${ }^{\circ}$, II). Entretanto, pecou a lei ao, revogando a Lei n. $^{\circ}$ 9.034, de 3 de maio de 1995, que regulava a utilização de meios operacionais para a prevenção e repressão de ações praticadas por organizações criminosas, ter previsto a possibilidade de captação ambiental como meio de prova sem, entretanto, exigir "autorização judicial", tal qual previa o art. 2. ${ }^{\circ}$, II, da revogada norma.

${ }^{81}$ Art. 5. ${ }^{\circ}$. (...) X - são invioláveis a intimidade, a vida privada, a honra e a imagem das pessoas, assegurado o direito a indenização pelo dano material ou moral decorrente de sua violação.

${ }^{82}$ Acolhendo esse entendimento, PACELLI, Eugênio (Curso de processo penal. 11. ed. São Paulo: Atlas, 2014. p. 348), observa que "quando um dos interlocutores promove a gravação da conversa sem o consentimento do outro, a ilicitude não ocorrerá, efetivamente, do fato da gravação. E isso porque o conteúdo da conversa empreendida foi disponibilizo àquele interlocutor; assim, porque conhecedor do conteúdo, não haveria problema na gravação feita por este. No entanto, quando referido conteúdo for disponibilizado, aí sim, poderá haver a afetação a direitos de terceiros. Nesse caso, embora lícita a gravação, a revelação de seu conteúdo poderia não sê-lo, afinal, o que ali teria sido dito não se destinava a mais ninguém, pois realizada no âmbito da intimidade dos interessados". Em mesmo sentido: BADARÓ, Gustavo Henrique Righi Ivahy. Processo penal. 4. ed. São Paulo: RT, 2016. p. 505.

Revista de Direito Brasileira | Florianópolis, SC | v. 26 | n. 10 | p. 365-386 | Mai./Ago. 2020 
admissibilidade das gravações clandestinas como elemento probatório no curso da ação penal, estabelecendo limites e vedações.

\section{O SUPREMO TRIBUNAL FEDERAL E AS GRAVAÇÕES CLANDESTINAS: AUSÊNCIA DE TRATAMENTO SISTEMÁTICO}

Por diversas vezes, o Supremo Tribunal Federal decidiu sobre a possibilidade de utilização das gravações clandestinas como meio de prova. Em um dos mais antigos precedentes sobre o tema, o RE n. ${ }^{\circ} 100.094 / \mathrm{PR}$, relatado pelo Ministro Rafael Mayer e analisado pela $1^{\text {a }}$ Turma em 28 de junho de 1984, entendeu-se pela ilicitude e desentranhamento dos autos, de prova obtida mediante a gravação clandestina da conversa entre um dos interlocutores, sem o conhecimento do outro.

No referido precedente, muito embora o Acórdão tivesse denunciado a existência de uma "interceptação de telefonema", tratava-se, na verdade, de uma gravação clandestina, no qual o diálogo, estabelecido entre o advogado de uma das partes e o impetrante de um mandado de segurança, desmentia o conteúdo de declaração escrita firmada pelo último em um embargo de terceiro. A conclusão do Pretório Excelso foi uma só: a prova não poderia ser utilizada nos autos para comprovar a alegação de uma das partes. Segundo o decidido, com fundamento no art. 153, § 9. ${ }^{\text {o83 }}$, da Emenda Constitucional n. ${ }^{\text {o }} 1$, de 17 de outubro de 1969:

Não há como negar, na verdade, independente de sua incursão no campo do ilícito penal (art. 151, § 1. ${ }^{\circ}$, II do CP; art. 56 e parág. único do $\mathrm{CBT}$ ), que o modo de captação desse meio de prova, feito à socapa, para servir, com a inciência do declarante, como dado a comprometer a sua integridade pessoal, incorre na infringência dos mais elementares princípios da ética e do mínimo de lealdade que deve presidir as relações humanas.

É uma prova desvestida, portanto, de legitimidade moral reclamada pelo art. 332 do CPC, e considera-la admissível é negar vigência a esse salutar preceito do nosso diploma processual.

Mas não é só, pois o entendimento dado pelo acórdão recorrido ao art. $153, \S 99^{\circ}$, da Constituição, admitindo que a conversação telefônica foi legitimamente gravada pela pessoa a quem se fez a comunicação e que é, portanto, da propriedade desta, importa, na verdade, em mutilar a garantia da inviolabilidade do sigilo das comunicações telefônicas, notadamente quando ela é quebrada em audiência pública com divulgação para conhecimento geral. (...)

Assim, o Recorrente se apresenta, no caso, com incontestável direito a ser amparado, no sentido de ser mantido o recato de sua comunicação telefônica, com destinação reservada, direito que está ameaçado de lesão pela sua publicidade em audiência de processo, em que não é parte, e pela sua admissão como meio de prova cujo processo de captação não é moralmente legítimo.

Em outro caso julgado pelo Supremo Tribunal Federal, mas agora em Plenário, a Suprema Corte decidiu no Inq n. ${ }^{\circ}$ 657/DF, julgado em 30 de setembro de 1993 e por maioria de votos, a admissibilidade de gravação clandestina realizada entre um servidor público federal que teria sofrido investidas do Ministro do Trabalho e Previdência Social para que participasse de um esquema de corrupção, no qual se agilizaria processos de parcelamento de débitos previdenciários em troca de propina.

\footnotetext{
${ }^{83}$ Art. 153. A Constituição assegura aos brasileiros e aos estrangeiros residentes no País a inviolabilidade dos direitos concernentes à vida, à liberdade, à segurança e à propriedade, nos têrmos seguintes: (...) § $9^{\circ}$ É inviolável o sigilo da correspondência e das comunicações telegráficas e telefônicas.
}

Revista de Direito Brasileira | Florianópolis, SC | v. 26 | n. 10 | p. 365-386 | Mai./Ago. 2020 
Com a negativa de participação do servidor e a insistência do Ministro de Estado, o primeiro teria, então, realizado a gravação realizada entre ambos, a fim de comprovar as insinuações do Ministro e, posteriormente, entregando-as a Polícia Federal. Submetido o julgamento à apreciação do Pretório Excelso, o Ministro Carlos Velloso, relator dos autos, entendeu inexistir ilicitude na gravação, posto que não haveria "ilicitude em gravar uma conversa que mantém com outrem, com a finalidade de documentá-la, futuramente, em caso de negativa".

Posteriormente a esse julgamento, o Plenário do Supremo Tribunal Federal, na AP n. ${ }^{\circ}$ 307/DF, ao analisar a possibilidade de utilização de uma conversa telefônica gravada clandestinamente por uma das testemunhas de acusação e dois réus, reconheceu, no julgamento realizado em 13 de dezembro de 1994 e já na vigência da Constituição Federal de 1988, a ilicitude da prova produzida, declarando-a nula por violação ao princípio do contraditório (art. $5 .^{\circ}, \mathrm{LV}$, da Constituição) e desrespeito à privacidade alheia (art. 5., X, da Constituição).

Conforme consta no Acórdão daquele julgamento, a gravação dos diálogos teria sido feita com uma secretária eletrônica e, posteriormente, entregue à Polícia Federal, sem o conhecimento dos interlocutores. Apesar de toda a discussão travada, inclusive resultando em três Ministros vencidos na discussão, a Suprema Corte entendeu que a imprestabilidade da gravação seria resultante do fato de a captação ter sido registrada sem o conhecimento de uma das partes.

De acordo com o Ministro Ilmar Galvão, relator do processo, impunha-se, como requisito para a autorização da gravação clandestina da conversa telefônica, o atendimento a três requisito: a existência de previsão legal, a prolação de ordem judicial autorizando a gravação e, por último, a observância de forma estabelecida pelo legislador. Em vista da ausência desses três requisitos, não haveria outro caminho senão considerar a prova ilícita, nos termos do art. 5. ${ }^{\circ}$, LVI, da Constituição.

Em mesmo sentido, o Ministro Moreira Alves, revisor daquela ação, defendeu que, muito embora não se cuidasse de interceptação telefônica, mas de gravação clandestina, com o consentimento de um dos interlocutores, inclusive, tal prova não poderia ser utilizada, uma vez que não se estaria presente a existência de justa causa que autorizasse a testemunha a gravar e entregar os diálogos a Polícia Federal, o que, nessa hipótese, excluiria a antijuridicidade da divulgação dessas gravações clandestinas.

Submetendo novamente a questão à apreciação do Plenário, o Supremo Tribunal Federal, em 11 de março de 1998, ao analisar o HC n. ${ }^{\circ}$ 75.338/RJ, que teve como relator o Ministro Nelson Jobim, entendeu como lícita a realização de gravação telefônica realizada por um dos interlocutores, sem o conhecimento do outro, num caso em que houve investida criminosa por um dos participantes do diálogo.

No caso em questão, um Juiz de Direito teria realizado ligações a um Tabelião Substituto, pedindo-lhe a quantia de US\$100.000,00 (cem mil dólares), em troca de uma possível solução a "situação" do notário junto a Corregedoria-Geral de Justiça do Tribunal de Justiça do Estado do Rio de Janeiro, onde o segundo respondia a processo disciplinar. Sentindo-se vítima de extorsão, os telefonemas foram gravados e, posteriormente, entregues ao Presidente do Tribunal e ao Ministério Público que, na sequência, denunciou o juiz pelo crime de exploração de prestígio (art. 357 do Código Penal).

Concluiu-se, naquela decisão, pela existência de justa causa na gravação clandestina realizada o que, em consequência, afastaria a alegação de violação ao direito à privacidade (art. 5. $\mathrm{X}$, da Constituição), a legitimá-la. De acordo com o voto do relator, seria inconsistente e feriria o senso comum, "falar-se em violação do direito à privacidade quando a própria vítima grava diálogo com sequestradores, estelionatários ou qualquer tipo de chantagista".

Finalmente, ao julgar o RE n. ${ }^{\circ}$ 583.937-QO-RG/RJ, o Plenário do Supremo Tribunal Federal em 19 de novembro de 2009, por meio do voto do relator, Ministro Cezar Peluso, entendeu constitucional a utilização da gravação clandestina realizada por um dos interlocutores, seja ela ambiental, seja ela relacionada à gravação telefônica, argumentando que nem um caso, nem o outro, 
poderiam ser vistos como interceptação. Assentou, assim, de forma irrestrita e aberta, a "admissibilidade do uso, como meio de prova, de gravação ambiental realizada por um dos interlocutores".

Dentre os argumentos utilizados para validar esse entendimento, alegou-se que ao revelar conversa do qual foi interlocutor, seja como emissor ou receptor, o indivíduo apenas disporia daquilo que lhe pertenceria e, portanto, não implicaria, como um terceiro, em violação ao sigilo das comunicações. A exceção a essa ideia se daria unicamente apenas se diante de indisponibilidade legal absoluta que fosse resultante de obrigação jurídica. Segundo o voto do Relator, seguido a quase unanimidade do Plenário,

É que assim os depoimentos pessoais, como os testemunhais soem exprimir o conteúdo de conversas entretidas, pelas partes e testemunhas, entre si, ou com outras pessoas, significando sempre, nesses casos, reprodução e divulgação do conteúdo da conversa entre presentes, ou até mantida por via telefônica, de um dos interlocutores, sem prévio assentimento ou conhecimento do outro, com resultado prático idêntico ao da semelhante revelação do teor de comunicação telefônica gravada, e, como tal, suscetível de idêntico juízo teórico de reprovabilidade jurídica. Que diferença há, para fins de justificação da existência de suposto dever de sigilo que recairia também sobre os próprios interlocutores, entre conversa mantida por telefone e a que se dá entre presentes? Ambas guardam a mesma particularidade de serem, enquanto estão ocorrendo, comunicações instantâneas, fugidias e desprovidas de vestígios materiais. E, qualquer que seja a modalidade ou o meio técnico usado para tanto, a revelação de uma em nada difere da revelação da outra, de modo que seria absurdo encontrar ilicitude num caso e licitude noutro.

Como se viu dos precedentes acima mencionados, muito embora o Excelso Pretório tenha reconhecido a licitude de gravações clandestinas, sejam elas ambientais ou telefônicas, a exigência imposta para que o direito à privacidade (art. 5., $\mathrm{X}$, da Constituição) pudesse ser rompido, residia justamente na exigência de que, para a divulgação da gravação realizada e a sua utilização no processo, houvesse justa causa por parte do interlocutor que a gravou.

Ao analisar, entretanto, o RE n. ${ }^{\circ}$ 583.937-QO-RG/RJ, de 2009, o Supremo Tribunal Federal passou a admitir, abertamente e sem quaisquer restrições, a não ser nos casos de expressa vedação legal ${ }^{84}$, a admissibilidade de toda e qualquer gravação clandestina, afastando não só o tratamento sistemático que a própria Suprema Corte vinha desenvolvendo, no qual exigia-se a presença de justa causa, mas, ainda, ampliando a utilização da gravação ambiental sem que fossem impostos quaisquer controles no seu emprego.

Abriram-se as portas, enfim, para que quaisquer captações clandestinas fossem validamente utilizadas como provas, permitindo-se, em consequência, toda gama de arbitrariedade e, o que é mais grave, negando-se não apenas o direito à privacidade como limite a produção probatória, mas, também, negando a própria previsão constitucional de vedação às provas ilícitas.

\footnotetext{
${ }^{84}$ Pode-se mencionar como hipótese de vedação legal, a disposição constante no art. 207 do Código de Processo Penal, pelo qual "são proibidas de depor as pessoas que, em razão de função, ministério, ofício ou profissão, devam guardar segredo, salvo se, desobrigadas pela parte interessada, quiserem dar o seu testemunho". Seria o caso, por exemplo, da tomada de depoimento de um advogado ou de um padre, os quais tem, segundo a previsão legal, o dever de segredo. Sobre as vedações a prova testemunhal: MARQUES, José Frederico. Elementos de direito processual penal. 1. ed. Rio de Janeiro: Forense, 1961. v. 2, p. 336; GOMES FILHO, Antonio Magalhães. Direito à prova no processo penal. 1. ed. São Paulo: RT, 1997. p. 128-130; FEITOZA, Denilson. Direito processual penal: teoria, crítica e práxis. 5. ed. Niterói: Impetus, 2008. p. 654; BADARÓ, Gustavo Henrique Righi Ivahy. Processo penal. 4. ed. São Paulo: RT, 2016. p. 470-471; DEZEM, Guilherme Madeira. Curso de processo penal. São Paulo: RT, 2015. p. 516-518; PACELLI, Eugênio. Curso de processo penal. 18. ed. São Paulo: Atlas, 2014. p. 416-417.
}

Revista de Direito Brasileira | Florianópolis, SC | v. 26 | n. 10 | p. 365-386 | Mai./Ago. 2020 


\section{A INTIMIDADE COMO LIMITE À ADMISSIBILIDADE DAS GRAVAÇÕES CLANDESTINAS: UMA PROPOSTA DE REVISÃO}

A indispensável preocupação com imposição de limitações à produção probatória já era manifestada por José Frederico Marques que, no início da década de 60, assentava o seu descontentamento com as provas que implicassem em violação a proteção e à garantia do indivíduo, bem como a adoção de medidas que lançassem "mão de meios condenáveis e iníquos de investigação e prova" 85 . Defendia, assim, serem condenáveis "os procedimentos desleais, como, por exemplo, a captação clandestina de telefonemas, o emprego de microfones dissimulados e do registro, em aparelhos eletrônicos, de conversações íntimas"86.

O direito à intimidade (art. $5 .^{\circ}, \mathrm{X}$, da Constituição), como já tratado no presente estudo ${ }^{87}$, configura um dos mais importantes limitadores ao direito à prova, permitindo que o indivíduo desenvolva a sua personalidade, longe de interferências arbitrárias ${ }^{88}$. Cuida-se, enfim, segundo Antonio Scarance Fernandes, do "espaço mais reservado do indivíduo no qual ele guarda os seus segredos e espera que não sejam descobertos" ${ }^{\$ 9}$.

Sendo esse contexto, tal qual já vinha sendo questionado pela doutrina ${ }^{90}$, entendemos da necessidade de revisão ao entendimento fixado pelo Supremo Tribunal Federal quanto à admissibilidade das gravações clandestinas, revendo-se o quanto decidido no RE n. ${ }^{\circ}$ 583.937-QO$\mathrm{RG} / \mathrm{RJ}$, a fim de que a licitude na utilização das provas obtidas mediante captação entre os interlocutores, seja ela ambiental ou telefônica, somente se dê quando presente hipótese de justa causa e se a prova captada cuidar diretamente de interesse daquele que realizou a gravação.

No que toca à primeira exigência, a presença de justa causa, tal pode ser compreendida como uma das excludentes de antijuridicidade (art. 23 do Código Penal ${ }^{91}$, permitindo-se, assim, que a conduta em questão se legitime em nome de outros interesses igualmente relevantes ${ }^{92}$. Referida hipótese pode ser aplicada ao processo penal mediante a analogia do art. 153 do Código Penal, pelo qual constitui crime "divulgar alguém, sem justa causa, conteúdo de documento particular ou de correspondência confidencial, de que é destinatário ou detentor, e cuja divulgação possa produzir dano a outrem".

Como justa causa, pode ser entendido, segundo os diversos exemplos sugeridos por Luiz Regis Prado, quando há o consentimento prévio do interessado, na hipótese de utilização do documento para a defesa judicial do remetente e do destinatário, inclusive de terceiro, desde que

\footnotetext{
${ }^{85}$ MARQUES, José Frederico. Elementos de direito processual penal. 1. ed. Rio de Janeiro: Forense, 1961. v. 2, p. 293.

${ }^{86}$ MARQUES, José Frederico. Elementos de direito processual penal. 1. ed. Rio de Janeiro: Forense, 1961. v. 2, p. 294.

${ }^{87}$ Sobre o direito à intimidade, cf., supra, item 2.

${ }^{88}$ GRINOVER, Ada Pellegrini. Liberdades públicas e processo penal: as interceptações telefônicas. 2. ed. São Paulo: RT, 1982.p. 87.

${ }^{89}$ FERNANDES, Antonio Scarance. Processo penal constitucional. 6. ed. São Paulo: RT, 2010. p. 104.

${ }^{90}$ MENDES, Gilmar Ferreira; BRANCO, Paulo Gustavo Gonet. Curso de direito constitucional. 6. ed. São Paulo: Saraiva, 2011. p. 599; PACELLI, Eugênio. Curso de processo penal. 18. ed. São Paulo: Atlas, 2014. p. 348-349; AVOLIO, Luiz Francisco Torquato. Provas ilícitas: interceptações telefônicas, ambientais e gravações clandestinas. 5. ed. São Paulo: RT, 2012. p. 217-218; AMBOS, Kai; LIMA, Marcellus Polastri Lima. O processo acusatório e a vedação probatória: perante as realidades alemã e brasileira. Porto Alegre: Livraria do Advogado, 2009. p. 171; GRINOVER, Ada Pellegrini Grinover; FERNANDES, Antonio Scarance; GOMES FILHO, Antonio Magalhães. As nulidades no processo penal. 9. ed. São Paulo: RT, 2006. p. 224; FERNANDES, Antonio Scarance. Processo penal constitucional. 6. ed. São Paulo: RT, 2010. p. 92.

${ }^{91}$ GRINOVER, Ada Pellegrini Grinover; FERNANDES, Antonio Scarance; GOMES FILHO, Antonio Magalhães. As nulidades no processo penal. 9. ed. São Paulo: RT, 2006. p. 224; PACELLI, Eugênio. Curso de processo penal. 18. ed. São Paulo: Atlas, 2014. p. 348-349; MENDES, Gilmar Ferreira; BRANCO, Paulo Gustavo Gonet. Curso de direito constitucional. 6. ed. São Paulo: Saraiva, 2011. p. 599.

${ }^{92}$ AVOLIO, Luiz Francisco Torquato. Provas ilícitas: interceptações telefônicas, ambientais e gravações clandestinas. 5. ed. São Paulo: RT, 2012. p. 217.
}

Revista de Direito Brasileira | Florianópolis, SC | v. 26 | n. 10 | p. 365-386 | Mai./Ago. 2020 
autorizado pelas partes, além das hipóteses de estado de necessidade (art. 23, I, do Código Penal), de legítima defesa (art. 23, II, do Código Penal) e, ainda, do estrito cumprimento de dever legal (art. 23, III, do Código Penal) ${ }^{93}$.

Assim, por exemplo, na hipótese no qual, em determinada reunião, um servidor público exija de seus subordinados a prática do crime de prevaricação, negando execução ao Código de Trânsito Brasileiro e, no curso do ato, ocorra a gravação ambiental dos diálogos estabelecidos entre as partes, inexistirá ilicitude da prova, uma vez que, nessa circunstância, tal foi precedida de justa causa, visando a preservação dos mesmos quanto às ordens ilícitas emanadas de autoridade superior $^{94}$.

O segundo requisito imprescindível para que a gravação clandestina possa ser tida como lícita, demanda a exigência de que a captação realizada diga respeito diretamente àquele que a captou $^{95}$. Manifestando-se em favor de terceiro, por exemplo, a prova será indiscutivelmente ilícita (art. 5. ${ }^{\circ}$, LVI, da Constituição) por violação ao princípio da privacidade (art. 5. ${ }^{\circ}$, X, da Constituição), devendo ser desentranhada dos autos (art. 157, caput, do Código de Processo Penal).

Ampara essa exigência o art. 233 e parágrafo único do Código de Processo Penal, pelo qual "as cartas particulares, interceptadas ou obtidas por meios criminosos, não serão admitidas em juízo", excepcionando-se essa hipótese, no entanto, quando as cartas forem exibidas "em juízo pelo respectivo destinatário, para a defesa de seu direito, ainda que não haja consentimento do signatário"96.

Afora o atendimento às exigências acima expostas, entendemos que a admissão da gravação clandestina implica em violação flagrante ao direito à privacidade, cuja relativização somente pode ser admitida nos casos em que a proteção do bem tutelado pelo art. $5^{\circ}, \mathrm{X}$, da Constituição, mostre-se inferior a outros bens jurídicos que estejam tutelados constitucionalmente $^{97}$, excepcionado, evidentemente, as hipóteses de prova ilícita pro reo, cuja análise impõe tratamento diverso ${ }^{98}$.

Demais disso, parece-nos equivocada a ideia, ao admitir o reconhecimento da licitude das gravações clandestinas de irrestrita, de que a gravação ambiental se equipararia a prova testemunhal. Ao contrário do entendimento manifestado, as captações clandestinas são produzidas não apenas sem que uma das partes tenha conhecimento de que está sendo gravada, mas, ainda, ocorrem no seio da privacidade dos interlocutores. A prova testemunhal, diferentemente, é produzida não só mediante contraditório estabelecido entre as partes, mas, também, com a consciência dos presentes, o que não acontece nas gravações clandestinas.

\footnotetext{
${ }^{93}$ PRADO, Luiz Regis. Curso de direito penal brasileiro: parte especial (arts. 121 a 249). 11. ed. São Paulo: RT, 2013. v. 2, p. 390. O autor cita ainda, dentre os exemplos, "se a divulgação tem por objetivo a comunicação de crime de ação pública (art. 5. $\left.{ }^{\circ}, \S 3 .^{\circ}, \mathrm{CPP}\right)$ ”. Entendemos, no entanto, que essa hipótese somente se aplica no caso de a vítima do delito ser parte na correspondência, afastando-se, em consequência, a utilização por terceiro.

${ }^{94}$ Cuida-se o exemplo, aliás, do caso narrado na AP n. ${ }^{\circ}$ 447/RS, julgado pelo Plenário do Supremo Tribunal Federal em 18 de fevereiro de 2009, em que entendeu-se como lícita gravação ambiental promovida, diante do fato de os interlocutores (fiscais de trânsito), terem se sentido "constrangidos, pelos réus, a praticar atos contrários a regras expressas em lei federal" (voto do revisor, Ministro Joaquim Barbosa).

95 PACELLI, Eugênio. Curso de processo penal. 18. ed. São Paulo: Atlas, 2014. p. 349. Em abono a esse posicionamento, MENDES, Gilmar Ferreira; BRANCO, Paulo Gustavo Gonet (Curso de direito constitucional. 6. ed. São Paulo: Saraiva, 2011. p. 599, afirmam que "a gravação ambiental será lícita quando utilizada pelo interessado para defender direitos seus, o que é suficiente para configurar a 'justa causa' como excludente da ilicitude do ato".

${ }^{96}$ Esse foi, aliás, o fundamento mencionado pelo Ministro Moreira Alves no julgamento da AP n. ${ }^{\circ}$ 307/DF. Na ocasião, anotou-se que "nesses casos, só não haverá prova ilícita se a gravação sub-reptícia for usada na defesa do direito de um dos interlocutores contra o outro em processo penal. É, aliás, o que está expresso no artigo 233, parágrafo único, do Código de Processo Penal, no tocante às cartas particulares".

${ }^{97}$ FERNANDES, Antonio Scarance. Processo penal constitucional. 6. ed. São Paulo: RT, 2010. p. 92.

${ }^{98}$ Não se admite, portanto, a aplicação da proporcionalidade pro societate. Em sentido contrário: AMBOS, Kai; LIMA, Marcellus Polastri Lima. O processo acusatório e a vedação probatória: perante as realidades alemã e brasileira. Porto Alegre: Livraria do Advogado, 2009. p. 172.
}

Revista de Direito Brasileira | Florianópolis, SC | v. 26 | n. 10 | p. 365-386 | Mai./Ago. 2020 
Entendemos, portanto, que a gravação ambiental impõe inegável violação a esfera individual, admitindo-a apenas restritamente e em casos determinados, quando conjugada a existência de justa causa e a utilização em favor do próprio interlocutor. Do contrário, como já pontuado por Karl Siegert, a liberdade de comunicação não faria sentido se, ela própria, fosse destruída pela possibilidade de registrar, clandestinamente, todas as palavras, com a consequência de deixar as pessoas viverem com o medo constante de serem controladas ${ }^{99}$.

Seria recomendável, enfim, a revisão no posicionamento firmado pelo Supremo Tribunal Federal (RE n. ${ }^{\circ}$ 583.937-QO-RG/RJ), evitando-se a banalização e a utilização de gravações clandestinas por violarem o direito à intimidade, estabelecendo-se vetores objetivos que, em situações pontuais e bem delimitadas, permitam a admissibilidade da prova quando presente a justa causa e o interesse daquele que a captou para defender interesse próprio.

\section{CONSIDERAÇÕES FINAIS}

Ao longo do presente estudo, buscamos apontar o direito à intimidade como limite à admissibilidade das gravações clandestinas no processo penal, notadamente a partir das alterações advindas com a Lei n. ${ }^{\circ} 11.690$, de 9 de junho de 2008, pela qual o Código de Processo Penal passou a dispor como ilícitas todas as provas que fossem produzidas em desrespeito não apenas a norma constitucional ou material, mas, também, processual.

Ao analisar o RE n. ${ }^{\circ}$ 583.937-QO-RG/RJ, o Supremo Tribunal Federal acabou por admitir, de forma geral e irrestrita, a gravação clandestina como meio lícito de prova, não apenas banalizando-a, mas, sobretudo, ignorando a necessidade de que o tema fosse objeto de necessária regulamentação quanto à sua utilização, exatamente como o próprio Pretório Excelso já vinha se manifestado ao longo dos anos.

Diante desse contexto, pensamos que deveria ocorrer a revisão do entendimento manifestado pela Suprema Corte, a fim de reconhecer, como regra geral, a ilicitude nas gravações clandestinas por violação ao direito à intimidade (art. 5. ${ }^{\circ}, \mathrm{X}, \mathrm{CF}$ ). Excepcionalmente, no entanto, desde que o interlocutor conjugue a presença de justa causa na captação, bem assim exista interesse direto daquele que a captou para a defesa de interesse próprio. Fora dessas hipóteses, a prova em questão será indiscutivelmente ilícita, devendo ser desentranhada dos autos, nos termos do art. 157, caput, do Código de Processo Penal.

\section{REFERÊNCIAS}

AMBOS, Kai; LIMA, Marcellus Polastri Lima. O processo acusatório e a vedação probatória: perante as realidades alemã e brasileira. Porto Alegre: Livraria do Advogado, 2009.

ALEXY, Robert. Teoria dos direitos fundamentais. 2. ed. São Paulo: Malheiros, 2015.

ANDRADE, Manuel da Costa. Sobre as proibições de prova em processo penal. Coimbra: Coimbra Editora, 1992.

AVOLIO, Luiz Francisco Torquato. Provas ilícitas: interceptações telefônicas, ambientais e gravações clandestinas. 5. ed. São Paulo: RT, 2012.

BADARÓ, Gustavo Henrique Righi Ivahy. Ônus da prova no processo penal. São Paulo: RT, 2003.

\footnotetext{
${ }^{99}$ SIEGERT, Karl. I limiti di legalità delle registrazioni e riproduzioni magnetofoniche effettuate nel processo penale. Rivista italiana di diritto e procedura penale, Milano, v. 4, n. 3, jul./set. 1957, p. 499.
}

Revista de Direito Brasileira | Florianópolis, SC | v. 26 | n. 10 | p. 365-386 | Mai./Ago. 2020 
BADARÓ, Gustavo Henrique Righi Ivahy. Processo penal. 4. ed. São Paulo: RT, 2016.

BADARÓ, Gustavo Henrique Righi Ivahy. Um modelo de epistemologia judiciária: o controle lógico e racional do juízo de fato no processo penal. 2018. Tese (Concurso de Professor Titular) Faculdade de Direito, Universidade de São Paulo, São Paulo.

BARROS, Marco Antonio de. A busca da verdade no processo penal. 2. ed. São Paulo: RT, 2010.

BONAVIDES, Paulo. Curso de direito constitucional. 26. ed. São Paulo: Malheiros, 2011.

D’URSO, Flávia. Princípio constitucional da proporcionalidade no processo penal. São Paulo: Atlas, 2007.

DEU, Teresa Armenta. La prueba ilícita: un estudio comparado. 2. ed. Madrid: Marcial Pons, 2011.

DEZEM, Guilherme Madeira. Curso de processo penal. São Paulo: RT, 2015.

FEITOZA, Denilson. Direito processual penal: teoria, crítica e práxis. 5. ed. Niterói: Impetus, 2008.

FERNANDES, Antonio Scarance. Processo penal constitucional. 6. ed. São Paulo: RT, 2010.

FURTADO, Régis Munari. Presunção de inocência e execução provisória da pena: evolução do tema no Supremo Tribunal Federal a partir da Constituição de 1988. 2019. Dissertação (Mestrado em Direito) - Faculdade de Direito, Pontifícia Universidade Católica de São Paulo, São Paulo.

GIACOMOLLI, José Nereu. O devido processo penal: abordagem conforme a Constituição Federal e o Pacto de São José da Costa Rica. São Paulo: Atlas, 2013.

GOMES FILHO, Antonio Magalhães. Direito à prova no processo penal. São Paulo: RT, 1997.

GÖSSEL, Karl Heinz. As proibições de prova no direito processual penal da República Federal da Alemanha. Revista Portuguesa de Ciência Criminal. Coimbra, v. 2, n. 3, jul./set. 1992.

GRECO FILHO, Vicente. Manual de processo penal. 10. ed. São Paulo: Saraiva, 2013.

GRINOVER, Ada Pellegrini Grinover; FERNANDES, Antonio Scarance; GOMES FILHO, Antonio Magalhães. As nulidades no processo penal. 9. ed. São Paulo: RT, 2006.

GRINOVER, Ada Pellegrini. Liberdades públicas e processo penal: as interceptações telefônicas. 2. ed. São Paulo: RT, 1982.

MARQUES, José Frederico. Elementos de direito processual penal. 1. ed. Rio de Janeiro: Forense, 1961. v. 2.

MENDES, Gilmar Ferreira; BRANCO, Paulo Gustavo Gonet. Curso de direito constitucional. 6. ed. São Paulo: Saraiva, 2011. 
MORAES, Maurício Zanoide de. Presunção de inocência no processo penal brasileiro: análise de sua estrutura normativa para a elaboração legislativa e para a decisão judicial. Rio de Janeiro: Lumen Juris, 2010.

PACELLI, Eugênio e FISCHER, Douglas. Comentários ao Código de Processo Penal e sua jurisprudência. 4. ed. São Paulo: Atlas, 2012.

PACELLI, Eugênio. Curso de processo penal. 18. ed. São Paulo: Atlas, 2014.

PACHECO, Denilson Feitoza. O princípio da proporcionalidade no direito processual penal brasileiro. Rio de Janeiro: Lumen Juris, 2007.

PEDROSO, Fernando de Almeida. Processo penal. O direito de defesa: repercussão, amplitude e limites. 3. ed. São Paulo: RT, 2001.

PIOVESAN, Flávia. Direitos humanos e o direito constitucional internacional. 12. ed. São Paulo: Saraiva, 2011.

PRADO, Luiz Regis. Curso de direito penal brasileiro: parte especial (arts. 121 a 249). 11. ed. São Paulo: RT, 2013. v. 2.

RANGEL, Paulo. Direito processual penal. 22. ed. São Paulo: Atlas, 2014.

SERRANO, Nicolas Gonzalez-Cuellar. Proporcionalidad y derechos fundamentales en el proceso penal. Madrid: Colex, 1990.

SIEGERT, Karl. I limiti di legalità delle registrazioni e riproduzioni magnetofoniche effettuate nel processo penale. Rivista italiana di diritto e procedura penale, Milano, v. 4, n. 3, jul./set. 1957.

SILVA, Marco Antonio Marques da Silva. Cidadania e democracia: instrumentos para a efetivação da dignidade humana. In: MIRANDA, Jorge; SILVA, Marco Antonio Marques da. (Coords.). Tratado luso-brasileiro da dignidade humana. 2. ed. São Paulo: Quartier Latin, 2009.

SILVA, Marco Antonio Marques da. Igualdade na persecução criminal: investigação e produção de provas nos limites constitucionais. In: SILVA, Marco Antonio Marques da. (Org.). Processo penal e garantias constitucionais. 1. ed. São Paulo: Quartier Latin, 2006.

SILVA, Marco Antonio Marques da. Refugiados são pessoas, dignas e com direitos. In: PINTO, Eduardo Vera-Cruz; PERAZZOLO, José Rodolpho; BARROSO, Luís Roberto; SILVA, Marco Antonio Marques da; CICCO, Maria Cristina de. (Coords.). Refugiados, imigrantes e igualdade dos povos: estudos em homenagem a António Guterres. São Paulo: Quartier Latin, 2017.

STRECK, Lenio Luiz. As interceptações telefônicas e os direitos fundamentais: Constituição, cidadania, violência: a Lei 9.296/96 e seus reflexos penais e processuais. Porto Alegre: Livraria do Advogado, 1997.

SZANIAWSKI, Elimar. Direitos de personalidade e sua tutela. São Paulo: RT, 1993.

TONINI, Paolo. A prova no processo penal italiano. São Paulo: RT, 2002. 